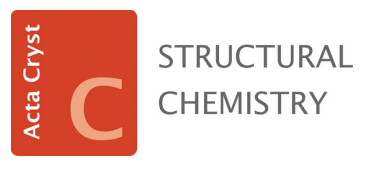

ISSN 2053-2296

Received 14 October 2015

Accepted 20 November 2015

Edited by P. Fanwick, Purdue University, USA

Keywords: Halichondrin B; eribulin mesylate; double stereodiffrentiation; asymmetric dihydroxylation; crystal structure; Karplus equation; anticancer drug; two-dimensional NMR; NOESY; COSY.

CCDC references: $1438133 ; 1438132$

Supporting information: this article has supporting information at journals.iucr.org/c

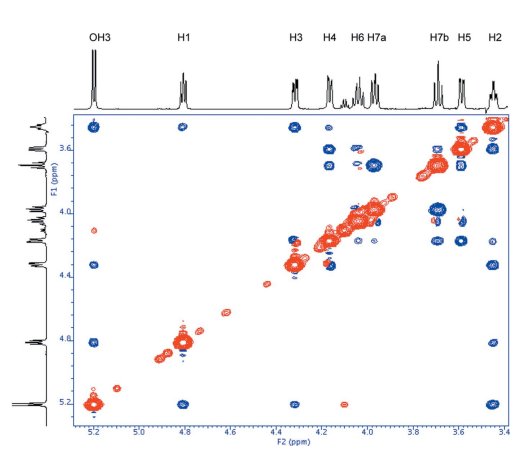

C 2016 International Union of Crystallography

\section{Structural corroboration of two important building blocks of the anticancer drug eribulin mesylate through two-dimensional NMR and single-crystal $\mathrm{X}$-ray diffraction studies}

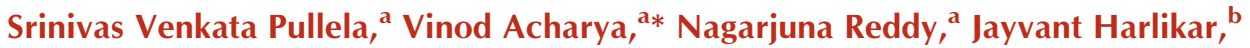 \\ Amar Kulkarni, ${ }^{\mathrm{b}}$ Rakesh Chavan, ${ }^{\mathrm{b}}$ Ajay Yadav, ${ }^{\mathrm{c}}$ Shuvendu Manna ${ }^{\mathrm{c}}$ and Angshuman
} Ghosh $^{\mathrm{c}}$

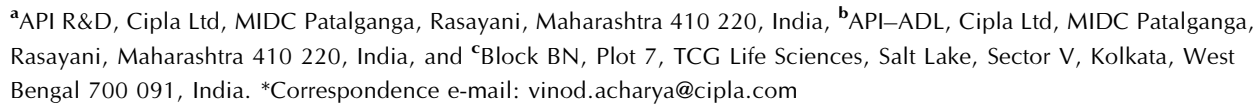

Eribulin mesylate, one of the most synthetically challenging drugs to date, possesses 19 stereocentres in its structure and ascertaining the absolute stereochemistry at every stage of the 64-stage synthesis is crucial. In our quest to synthesize eribulin, we identified two critical building blocks of this molecule, namely 3,4:6,7-di- $O$-cyclohexylidene-D-glycero- $\alpha$-L-talo-heptopyranose methanol monosolvate, $\mathrm{C}_{19} \mathrm{H}_{30} \mathrm{O}_{7} \cdot \mathrm{CH}_{3} \mathrm{OH}$, and $(2 R, 3 R, 4 R, 5 S)$-5-allyl-2-[(S)-2,3-dihydroxypropyl]-4-[(phenylsulfonyl)methyl]tetrahydrofuran-3-ol, $\mathrm{C}_{17} \mathrm{H}_{24} \mathrm{O}_{6} \mathrm{~S}$, for which two-dimensional NMR (2D-NMR) data were not sufficient to prove the absolute configuration. To ensure structural integrity, single-crystal X-ray diffraction data were obtained to confirm the structures. This information provides useful insights into the structural framework of the large eribulin mesylate molecule.

\section{Introduction}

Eribulin mesylate is a structurally truncated synthetic analogue of Halichondrin B (Hirata \& Uemura, 1986; Kishi et al., 1994), the most bioactive natural product isolated from the marine sponge Halichondria okadai commonly found off the coasts of Japan and New Zealand. Eribulin mesylate $\left(\right.$ Halaven ${ }^{\mathbb{R}}$ ) interferes with microtubule dynamics (Smith et al., 2010) and was approved in November 2010 by the United States Food and Drug Administration (USFDA) for the treatment of metastatic breast cancer (Towle et al., 2001). The structure of eribulin resembles a macrocyclic ketone showcasing a fully synthetic drug available on the market today. 19 of the $36 \mathrm{C}$ atoms that constitute the skeleton of the molecule are stereogenic in nature.

The structural framework of eribulin is built up by assembling three key fragments: (i) the $\mathrm{C} 1-\mathrm{C} 13$ aldehyde fragment (I), (ii) the C14-C26 vinyl triflate fragment (II) and (iii) the C27-C35 phenyl sulfone fragment (III) (Fig. 1).

Several synthetic routes have been used for the preparation of eribulin, (V), each of which utilize the same strategy described by Kishi and co-workers, known for their pioneering work on the total synthesis of Halichondrins, and Halichondrin B in particular (Aicher et al., 1992). Over the years, synthetic routes have evolved continuously, with scale-up and route refinement as the key areas of improvement (Yu et al., 2013; Austad et al., 2013). 


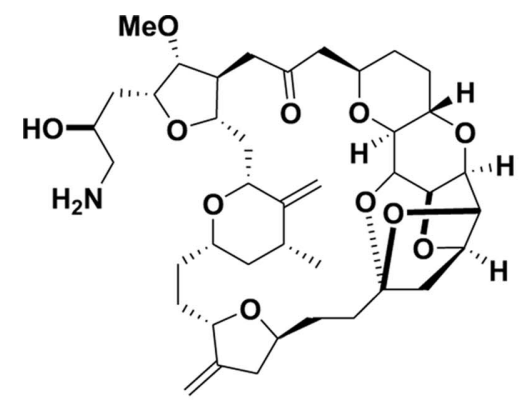

Eribulin Mesylate

(V)

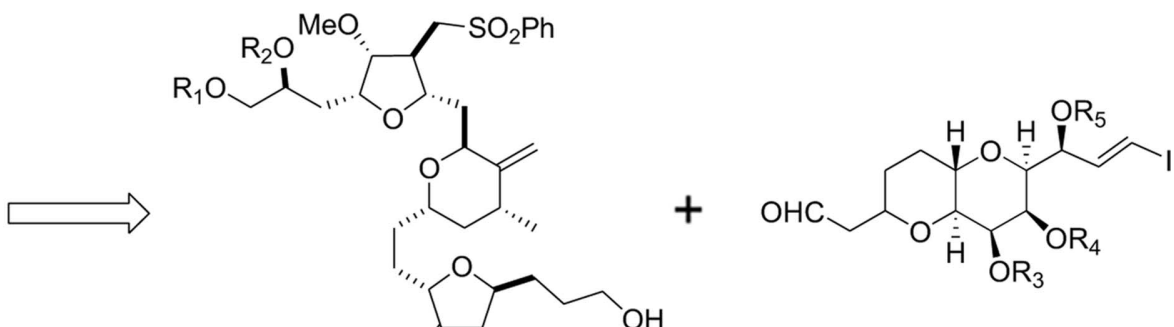

C1-C13 aldehyde fragment I

(I)

\section{4-C35 fragment}

(IV)

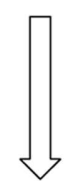

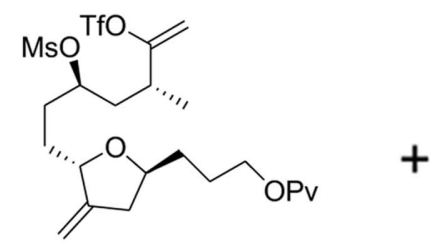

C14-C26 triflate fragment II

(II)

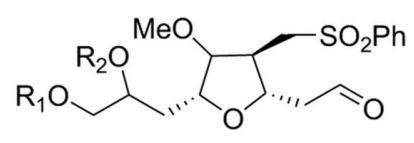

C27-C35 sulfone fragment III (III)

Figure 1

Retero-synthetic scheme for the coupling of fragments I and IV, and the construction of eribulin molecule (V).

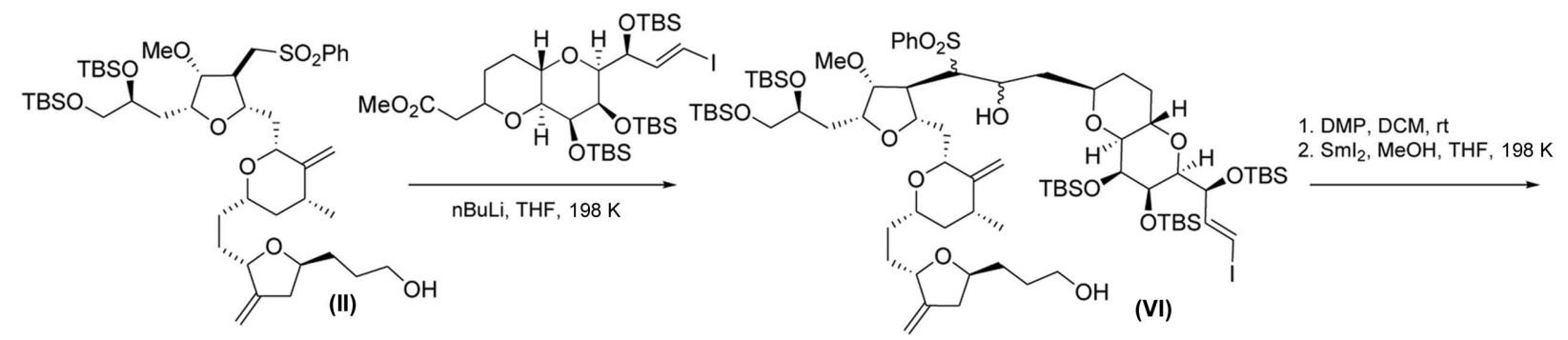

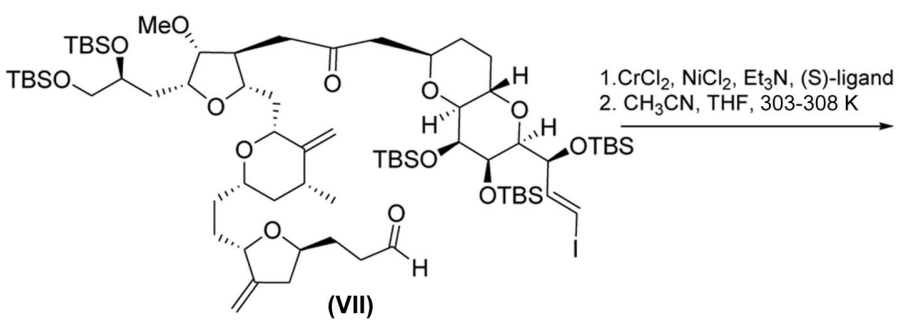

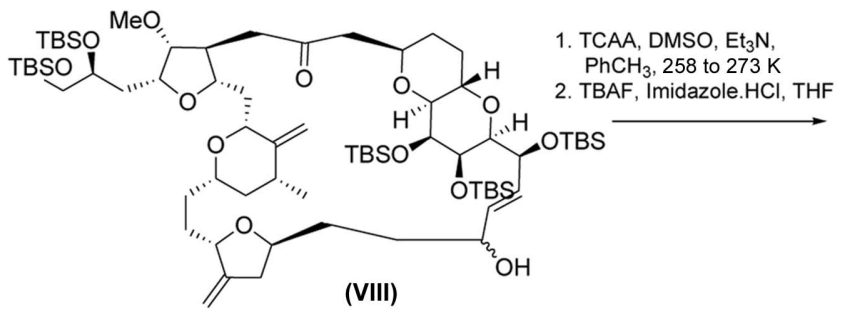

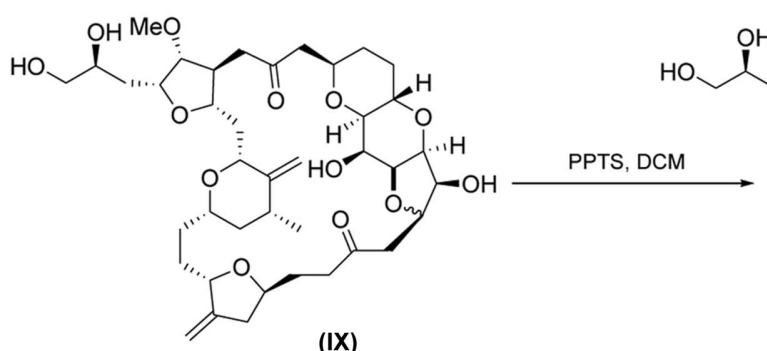

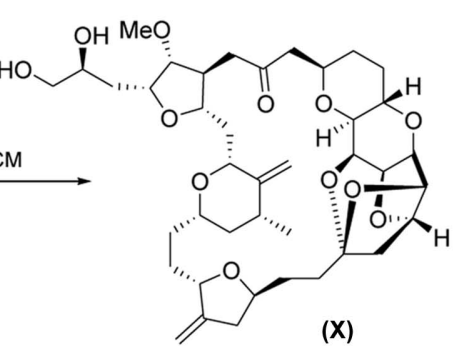

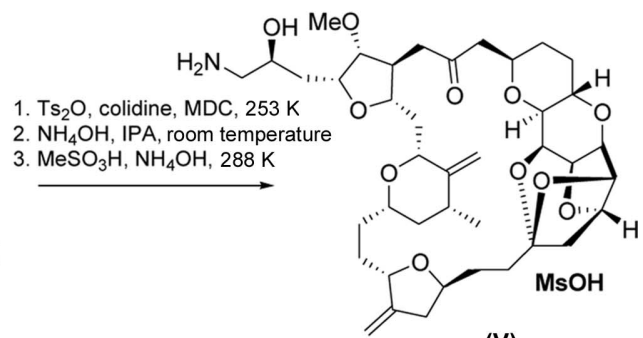

Figure 2

The final stages in the synthesis of eribulin mesylate, (V). 

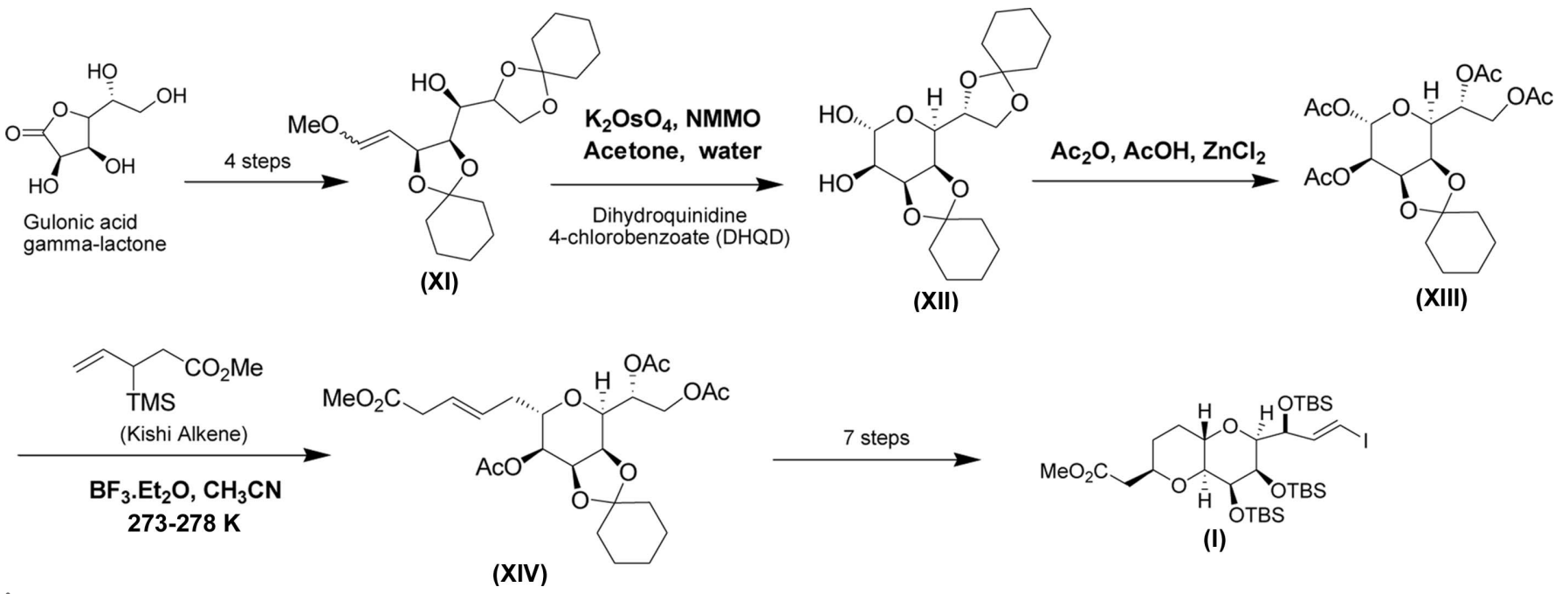

Figure 3

An overview of the synthetic scheme for the preparation of (I).

The three key fragments (I)-(III) (Fig. 1) are synthesized in 15-20 stages each and have been reported in detail. In the later stages, (II) and (III) are subjected to Nozaki-HiyamaKishi (NHK) coupling (Hiyama et al., 1981; Jin et al., 1986) to yield fragment (IV) (the C14-C35 fragment) (Fig. 1), which is then coupled with (I) under basic conditions. The final stages (Fig. 2) involve a macrocyclization achieved again through NHK coupling of (VIII), the formation of cyclic ketal (IX) and the conversion of terminal diol (X) to an in situ epoxide on which the primary amine is added to finally realize eribulin mesylate, (V).<smiles>CO[C@H](C[C@H]1O[C@H](CCOC(=O)c2cc([N+](=O)[O-])cc([N+](=O)[O-])c2)[C@@H](CS(=O)(=O)c2ccccc2)[C@@H]1OC)OC(=O)c1ccccc1</smiles>

(IIla) (Yang et al., 2009)

\section{Scheme 1}

The goal of our synthesis was to conduct feasibility studies and develop an optimized and scalable process for the preparation of $(\mathrm{V})$. Owing to the presence of 19 stereocentres in this molecule, it was required to continuously ensure the correct stereoisomer at every stage of this extensive synthesis. The important check-point was to characterize newly formed stereocentres in selected molecules through two-dimensional NMR (2D-NMR) data. There were, however, instances where 2D-NMR data were not conclusive enough to prove the absolute stereochemistry or there was a need to prove the molecular geometry for subsequent reactions. Hence, singlecrystal X-ray diffraction analysis was employed to identified intermediates of compounds (I)-(III) in order to conclusively establish the structures (Fig. 1).

The single-crystal X-ray structure of (IV) has been reported previously (Austad et al., 2013). Also, a 3,5-dinitrophenyl ester derivative of the alcohol variant of (III) (Fig. 1) has been reported, denoted (III a) (Yang et al., 2009) (Scheme 1).

We report here the single-crystal X-ray data for two relatively important intermediates of (I) and (III) which have an important bearing on the structural orchestration of the eribulin molecule.

The selected intermediate of (I) is 3,4:6,7-di- $O$-cyclohexylidene-D-glycero- $\alpha$-L-talo-heptopyranose, (XII) (Scheme 2), whose stereochemistry has important implications for the Callylation product (XIV) two stages later (Fig. 3). The synthesis of (I) starts with D-gulono- $\gamma$-lactone (Fig. 3) having two sets of vicinal diol groups, the stereochemistries of which are fixed. The D-gulono- $\gamma$-lactone is converted into its lactol which reacts with $\mathrm{MeOCH}_{2} \mathrm{PPh}_{3} \mathrm{Cl}$ under Wittig conditions to produce hydroxyalkene (XI). The Sharpless dihydroxylation protocol through which (XII) is finally obtained involves a

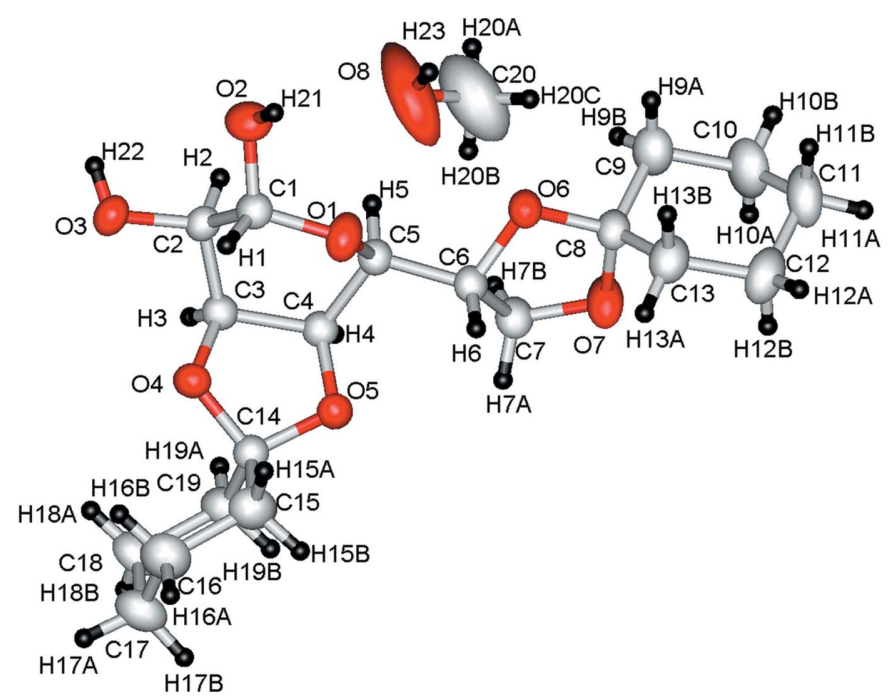

Figure 4

The molecular structure of (XII), showing atom H1 in a different plane to the other $\mathrm{H}$ atoms of the cyclohexylidene ring. Displacement ellipsoids are drawn at the $50 \%$ probability level. 
catalytic osmylation (Kolb et al., 1994) of (XI) using the double stereo-differentiation strategy (Masamme et al., 1985). It provides a 4:1 mixture of diastereoisomers, which after purification delivers (XII) as a single diastereoisomer in the form of a white crystalline solid. This mechanism should force the $\mathrm{H}$ atom on $\mathrm{C} 1$ (i.e. $\mathrm{H} 1$ ) to lie on the opposite side of the tetrahydropyran ring plane in the desired diastereoisomer, compared with the other $\mathrm{H}$ atoms on atoms C2-C5 (Fig. 4). However, the nuclear Overhauser effect spectroscopy (NOESY) (Fig. 5) of this molecule unusually showed that atom $\mathrm{H} 1$ has an interaction with $\mathrm{H} 2$, which normally means that they are on the same side of the tetrahydropyran ring plane. Further insight into this molecule could be provided by using single-crystal X-ray diffraction to align the mechanistic rationale and determine the absolute configuration. Compound (XII) is then subjected to acetylation yielding tetraacetate (XIII). C-Allylation of (XIII) using methyl 3-(trimethylsilyl)pent-4-enoate (also known as the Kishi alkene) retains the configuration on $\mathrm{C} 1$ after displacement of the $O$-acetyl group to yield allylic ester (XIV) which exists as a 1:1 mixture of conformers (Stamos \& Kishi, 1996).

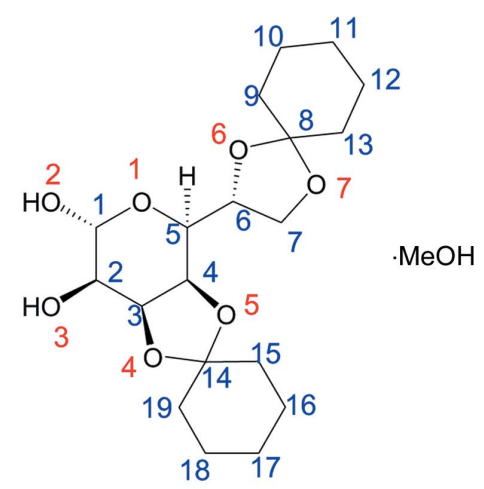

(XII)

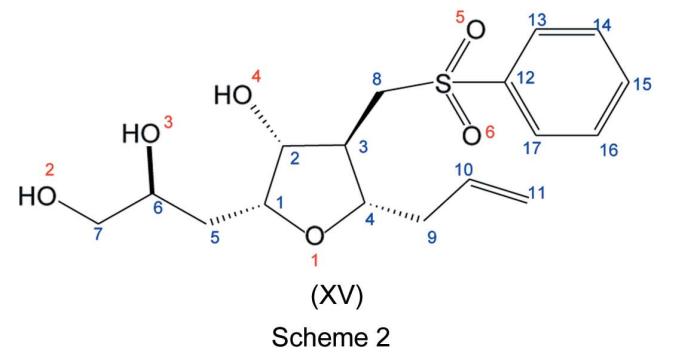

The second intermediate, $(2 R, 3 R, 4 R, 5 S)-5$-allyl-2-[( $S)-2,3-$ dihydroxypropyl]-4-[(phenylsulfonyl)methyl]tetrahydrofuran3-ol, (XV) (Scheme 2), from the synthesis of (III) is obtained through a sequence of 15 chemical transformations (Fig. 6) starting from D-glucorono-6,3-lactone (Yang et al., 2009). The correlation NMR spectra (COSY) of the tetrahydrofuran framework present in $(\mathrm{V})$ and its intermediates show that the vicinal $\mathrm{H}$ atoms on $\mathrm{C} 2$ and $\mathrm{C} 3$ do not correlate. It became vital to understand the spatial orientation of these two $\mathrm{H}$ atoms along with the structural framework so as to deduce the relative configuration of this molecule. Further, the $\mathrm{C} 6-\mathrm{C} 7$ diol functionality is introduced through asymmetric dihydroxylation in a 3:1 diastereoisomeric ratio in (XX). The undesired isomer after two stages at (XXI) is removed

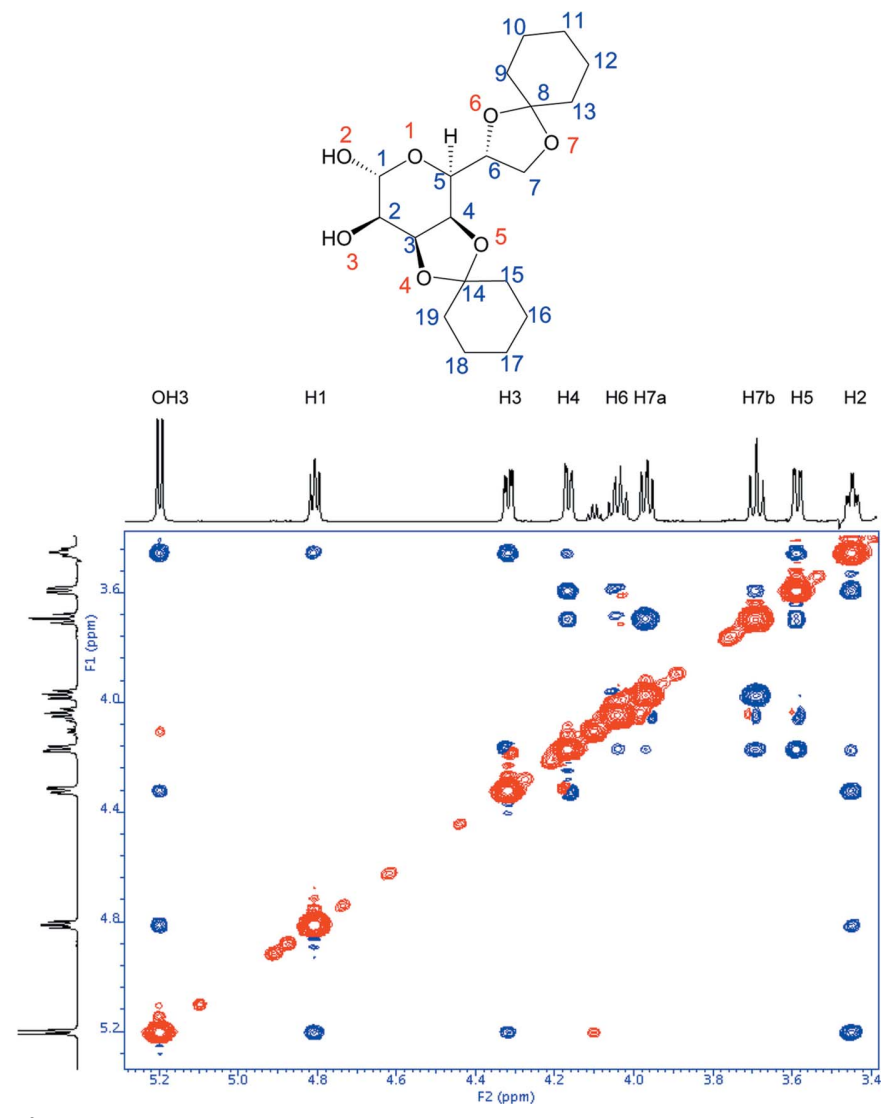

Figure 5

The 2D-NOESY spectrum of (XII).

through recrystallization. Our attempts to prepare single crystals of (XXI) were unsuccessful. We then went five stages further to triol (XV) (Fig. 4) which exists as a white crystalline solid and was successful crystallized.

\section{Experimental}

\subsection{General considerations}

Compounds (XII) and (XV) were prepared according to existing synthesis routes (Charles et al., 2013; Brian et al., 2013). NMR spectra were recorded at room temperature using an Agilent $500 \mathrm{MHz}$ spectrometer. ${ }^{1} \mathrm{H}$ chemical shifts are reported in p.p.m. referenced to tetramethylsilane (TMS, 0.0 p.p.m.). ${ }^{13} \mathrm{C}$ chemical shifts are reported in p.p.m. referenced to the solvent resonance of 39.5 p.p.m. for DMSO- $d_{6}$.

\subsection{NMR data}

2.2.1. ${ }^{1} \mathrm{H}$ and ${ }^{13} \mathrm{C}$ NMR data for (XII). ${ }^{1} \mathrm{H}$ NMR $(500 \mathrm{MHz}$, DMSO- $\left.d_{6}\right): \delta 1.30-1.35(m, 4 \mathrm{H}), 1.42-1.60(m, 16 \mathrm{H}), 3.43-3.44$ $(d d, J=3 \mathrm{~Hz}, 1.5 \mathrm{~Hz}, 1 \mathrm{H}), 3.56-3.58(d d, J=2,1.5 \mathrm{~Hz}, 1 \mathrm{H})$, 3.66-3.69 ( $t, 1 \mathrm{H}), 3.94-3.97(q, 1 \mathrm{H}), 4.00-4.05(q, 1 \mathrm{H}), 4.14-$ $4.16(d d, J=2.5,1.5 \mathrm{~Hz}, 1 \mathrm{H}), 4.29-4.32(d d, J=2.5,3 \mathrm{~Hz}, 1 \mathrm{H})$, 4.79-4.80 $(d, J=6 \mathrm{~Hz}, 1 \mathrm{H}), 5.23-5.24(d, 1 \mathrm{H}), 6.34-6.35(d$, $1 \mathrm{H}) .{ }^{13} \mathrm{C}$ NMR $\left(125 \mathrm{MHz}, \mathrm{DMSO}-d_{6}\right): \delta 23.38\left(-\mathrm{CH}_{2}\right), 23.44$ $\left(-\mathrm{CH}_{2}\right), 23.50\left(-\mathrm{CH}_{2}\right), 23.62\left(-\mathrm{CH}_{2}\right), 24.63\left(-\mathrm{CH}_{2}\right), 24.66$ $\left(-\mathrm{CH}_{2}\right), 34.60\left(-\mathrm{CH}_{2}\right), 34.98\left(-\mathrm{CH}_{2}\right), 35.47\left(-\mathrm{CH}_{2}\right), 35.86$ $\left(-\mathrm{CH}_{2}\right), 64.78\left(-\mathrm{CH}_{2}\right), 68.87(-\mathrm{CH}), 70.93(-\mathrm{CH}), 74.20(-\mathrm{CH})$, 
Table 1

Experimental details.

(XII)

$\mathrm{C}_{19} \mathrm{H}_{30} \mathrm{O}_{7} \cdot \mathrm{CH}_{4} \mathrm{O}$
402.48
Orthorhombic, $P 2_{1} 2_{1} 2_{1}$
293
$7.2240(18), 12.935(3), 22.0691(10)$
$2062.2(7)$
4
Mo $K \alpha$
0.10
$0.20 \times 0.20 \times 0.20$

Rigaku XtaLAB mini diffractometer Numerical (NUMABS; Rigaku, 1999) $0.967,0.980$

20377, 4735, 4568

0.027

0.649

$0.037,0.100,1.08$
4735
256
H-atom parameters constrained
$0.29,-0.29$
Flack $x$ determined using 1853 quotients
$\quad\left[\left(I^{+}\right)-\left(I^{-}\right)\right] /\left[\left(I^{+}\right)+\left(I^{-}\right)\right]$(Parsons et al.,
$\quad 2013)$
$0.0(3)$

(XV)

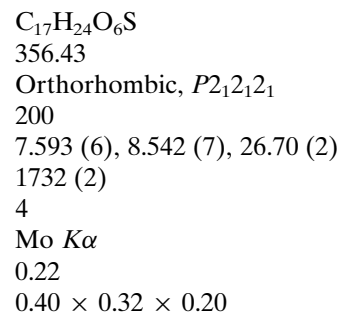

Rigaku XtaLAB mini diffractometer Numerical (NUMABS; Rigaku, 1999) $0.887,0.958$

$14279,3942,3733$

0.034

0.650

$0.033,0.082,1.05$

3942

220

$\mathrm{H}$-atom parameters constrained

$0.23,-0.24$

Flack $x$ determined using 1453 quotients $\left[\left(I^{+}\right)-\left(I^{-}\right)\right] /\left[\left(I^{+}\right)+\left(I^{-}\right)\right]$(Parsons et al. 2013) $0.00(3)$

Absolute structure parameter

Computer programs: CrystalClear-SM Expert (Rigaku, 2014), SIR92 (Altomare et al., 1994), SHELXL2014 (Sheldrick, 2015) and CrystalStructure (Rigaku, 2015).

$74.85(-\mathrm{CH}), 75.65(-\mathrm{CH}), 93.59(-\mathrm{CH}), 108.84$ (quaternary C), 109.48 (quaternary C). The NMR spectra are available in the Supporting information.

2.2.2. ${ }^{1} \mathrm{H}$ and ${ }^{13} \mathrm{C}$ NMR data for (XV). ${ }^{1} \mathrm{H}$ NMR $(500 \mathrm{MHz}$, DMSO- $\left.d_{6}\right): \delta 1.51-1.53(m, 1 \mathrm{H}), 1.69-1.71(m, 1 \mathrm{H}), 2.00-2.01$ $(t, 1 \mathrm{H}), 2.22-2.54(m, 2 \mathrm{H}), 3.25-3.28(m, 2 \mathrm{H}), 3.31-3.32(d$, $1 \mathrm{H}), 3.43-3.47(m, 2 \mathrm{H}), 3.53-3.54(q, 1 \mathrm{H}), 3.72-3.73(q, 1 \mathrm{H})$, 3.95-3.97 $(t, 1 \mathrm{H}), 4.39-4.42(m, 2 \mathrm{H}), 4.80-4.81(d, J=5 \mathrm{~Hz}$, $1 \mathrm{H}), 4.87-4.90(t, 2 \mathrm{H}), 5.61-5.69(m, 1 \mathrm{H}), 7.64-7.67(t, 2 \mathrm{H})$, $7.73-7.76(t, 1 \mathrm{H}), 7.92-7.93(d, J=8 \mathrm{~Hz}, 2 \mathrm{H}) .{ }^{13} \mathrm{C} \mathrm{NMR}$ $\left(125 \mathrm{MHz}, \mathrm{DMSO}-d_{6}\right): \delta 32.53\left(-\mathrm{CH}_{2}\right), 38.75\left(-\mathrm{CH}_{2}\right), 47.49$ $(-\mathrm{CH}), 56.52\left(-\mathrm{CH}_{2}\right), 65.80\left(-\mathrm{CH}_{2}\right), 68.89(-\mathrm{CH}), 75.75(-\mathrm{CH})$, $78.64(-\mathrm{CH}), 81.20(-\mathrm{CH}), 116.67\left(-\mathrm{CH}_{2}\right), 127.78$ (2-aryl-CH), 129.38 (2-aryl-CH), $133.83(-\mathrm{CH}), 135.06(-\mathrm{CH}), 139.31$ (quaternary C). The NMR spectra are available in the Supporting information.

\subsection{Crystallization}

Compound (XII) was crystallized by slow evaporation from a solution in methanol, yielding crystals suitable for singlecrystal X-ray diffraction analysis. Compound (XV) was recrystallized by slow evaporation from a solution in a mixture of toluene and $n$-butanol $(7: 1 v / v)$, yielding crystals in the form of colourless prisms ideal for single-crystal X-ray diffraction analysis.

\subsection{Refinement}

Crystal data, data collection and structure refinement details for (XII) and (XV) are summarized in Table 1. $\mathrm{H}$ atoms were placed in geometrically optimized positions and constrained to ride on their parent atoms, with $\mathrm{C}-\mathrm{H}=0.96$ (methyl), 0.97 (methylene) or $0.98 \AA$ (methine) and $\mathrm{O}-\mathrm{H}=0.82 \AA$ for (XII), and $\mathrm{C}-\mathrm{H}=0.95$ (aryl), 0.99 (methylene) or $1.00 \AA$ (methine) and $\mathrm{O}-\mathrm{H}=0.84 \AA$ for $(\mathrm{XV})$. Displacement parameters for all $\mathrm{H}$ atoms were assigned as $U_{\text {iso }}(\mathrm{H})=1.2 U_{\text {eq }}(\mathrm{C}, \mathrm{O})$. The orientation of the solvent methyl group in (XII) was allowed to rotate about the $\mathrm{C}-\mathrm{O}$ bond to find the best fit to the observed electron-density peaks and the hydroxy groups in (XV) were similarly allowed to rotate. For (XII), the hydroxy groups at $\mathrm{O} 3$ and $\mathrm{O} 9$ were also treated this way, but the hydroxy group at $\mathrm{O} 2$ was oriented such that the $\mathrm{H}$ atom was in a staggered position with respect to the substituents on the parent $\mathrm{C}$ atom.

For compound (XII), the chosen absolute configuration of the model was based on known stereochemistry as discussed below, whereas for (XV), the absolute stereochemistry was deduced independently from Parson's $z$ parameter [0.00 (3); Parsons et al., 2013].

\section{Results and discussion}

The single-crystal X-ray structure of (XII) (Fig. 4) shows that the compound crystallizes in a 1:1 ratio with methanol solvent 

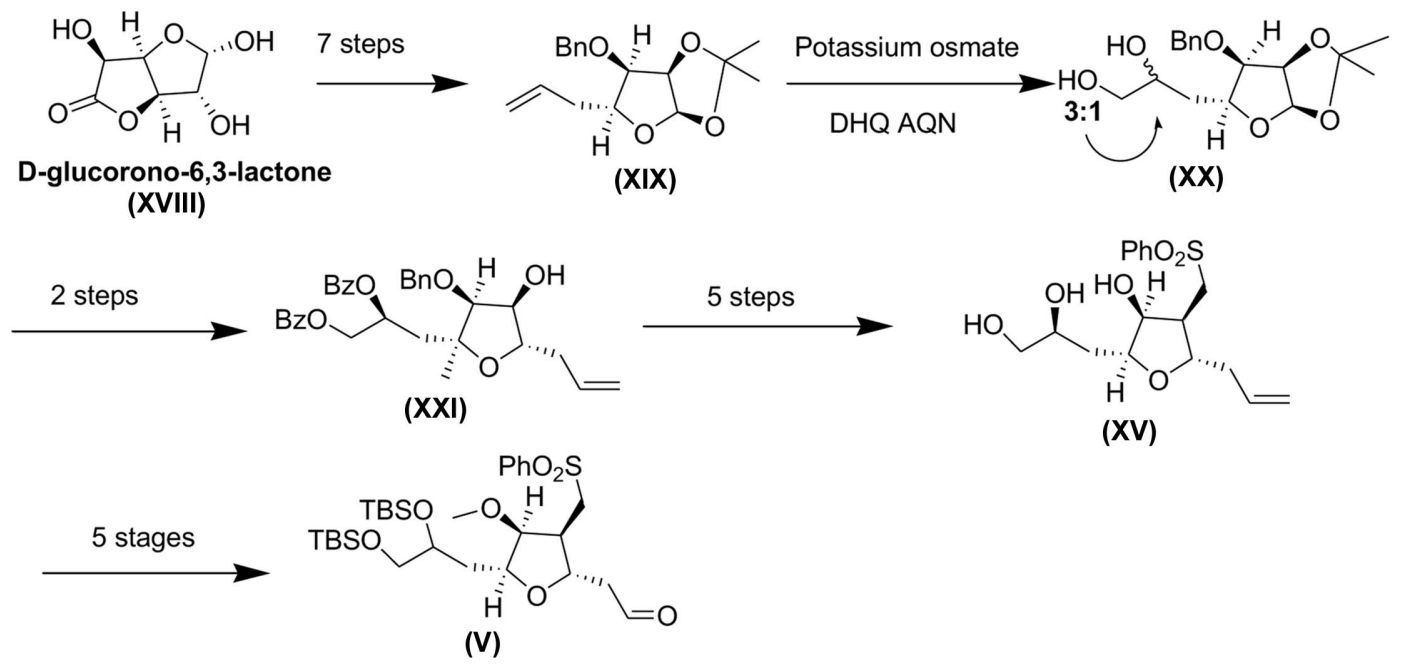

Figure 6

An overview of the synthetic scheme for the preparation of $(\mathrm{V})$.

Table 2

Hydrogen-bond geometry $\left(\AA,^{\circ}\right)$ for (XII).

\begin{tabular}{lllll}
\hline$D-\mathrm{H} \cdots A$ & $D-\mathrm{H}$ & $\mathrm{H} \cdots A$ & $D \cdots A$ & $D-\mathrm{H} \cdots A$ \\
\hline $\mathrm{O} 2-\mathrm{H} 21 \cdots \mathrm{O} 8^{\mathrm{i}}$ & 0.82 & 1.98 & $2.653(3)$ & 139 \\
$\mathrm{O}^{\mathrm{O}}-\mathrm{H} 22 \cdots 6^{\mathrm{ii}}$ & 0.82 & 2.02 & $2.829(2)$ & 171 \\
$\mathrm{O} 8-\mathrm{H} 23 \cdots \mathrm{O}^{\mathrm{i}}$ & 0.82 & 1.92 & $2.727(3)$ & 169 \\
\hline
\end{tabular}

Symmetry codes: (i) $x-\frac{1}{2},-y+\frac{3}{2},-z+1$; (ii) $x+\frac{1}{2},-y+\frac{3}{2},-z+1$.

Table 3

Hydrogen-bond geometry $\left(\AA,^{\circ}\right)$ for $(\mathrm{XV})$.

\begin{tabular}{lllll}
\hline$D-\mathrm{H} \cdots A$ & $D-\mathrm{H}$ & $\mathrm{H} \cdots A$ & $D \cdots A$ & $D-\mathrm{H} \cdots A$ \\
\hline $\mathrm{O} 2-\mathrm{H} 18 \cdots \mathrm{O} 1^{\mathrm{i}}$ & 0.84 & 2.05 & $2.859(3)$ & 161 \\
$\mathrm{O} 2-\mathrm{H} 18 \cdots \mathrm{O} 3$ & 0.84 & 2.46 & $2.817(3)$ & 107 \\
$\mathrm{O} 3-\mathrm{H} 19 \cdots \mathrm{O} 4^{\mathrm{ii}}$ & 0.84 & 1.98 & $2.813(3)$ & 172 \\
$\mathrm{O} 4-\mathrm{H} 20 \cdots \mathrm{O} 2^{\mathrm{iii}}$ & 0.84 & 1.89 & $2.719(3)$ & 171
\end{tabular}

Symmetry codes: (i) $-x, y-\frac{1}{2},-z+\frac{3}{2}$; (ii) $-x+1, y-\frac{1}{2},-z+\frac{3}{2}$; (iii) $x+1, y, z$.

molecules. The cyclohexylidene rings assume chair conformations, whereas the five-membered rings have envelope conformations. The molecules pack together in the solid state with a few intermolecular hydrogen bonds. The O2 and O3 hydroxy groups form hydrogen-bonding interactions with methanol atom $\mathrm{O}^{\mathrm{i}}$ and with the $\mathrm{O}^{\mathrm{ii}}$ atom of another molecule, respectively (Table 2). These interactions link the constituents into extended chains which run parallel to the [100] direction.

The NOESY spectrum of (XII) (Fig. 5) shows that the $\mathrm{H}$ atom at $\mathrm{C} 1$ (H1, 4.8 p.p.m.) has an interaction with $\mathrm{H} 2$, which was unexpected from mechanistic considerations. The singlecrystal X-ray diffraction data, however, confirm the mechanistic rationale wherein atom $\mathrm{H} 1$ lies on the opposite side of the ring plane from the other $\mathrm{H}$ atoms (those on on $\mathrm{C} 2, \mathrm{C} 3, \mathrm{C} 4$ and C5) of the tetrahydropyran ring. Furthermore, the $\mathrm{H} 1 \cdots \mathrm{H} 2$ distance of $2.83 \AA$ supports a NOESY interaction between these atoms. The interatomic distance between atoms $\mathrm{C} 1$ and C2 is 1.523 (3) ̊. Also, atoms H1 and H5 are on opposite sides of the $\mathrm{C} 1-\mathrm{O} 1-\mathrm{C} 5$ unit, with an $\mathrm{H} 1 \cdots \mathrm{H} 5$ interatomic distance of $3.55 \AA$. The interatomic distance between atoms $\mathrm{C} 1$ and $\mathrm{H} 5$ is $2.68 \AA$, and that between atoms C5 and H1 is $3.12 \AA$.

We further focused our attention on the starting material, i.e. $\mathrm{D}$-gulono- $\gamma$-lactone, which has a specific optical rotation (SOR) of $-55^{\circ}$. The stereochemistry at atoms C3 and C4 in this molecule are fixed and this is carried through onto atoms C3 and C4 in (XII). Because the known stereochemistry at atoms $\mathrm{C} 3$ and $\mathrm{C} 4$ remains fixed during the synthesis, the crystal structure allows the configuration of all stereocentres in (XII) to be established relative to those. We were thus able to establish the absolute configuration of (XII) in this manner with the aid of both the NOESY and the single-crystal X-ray data.

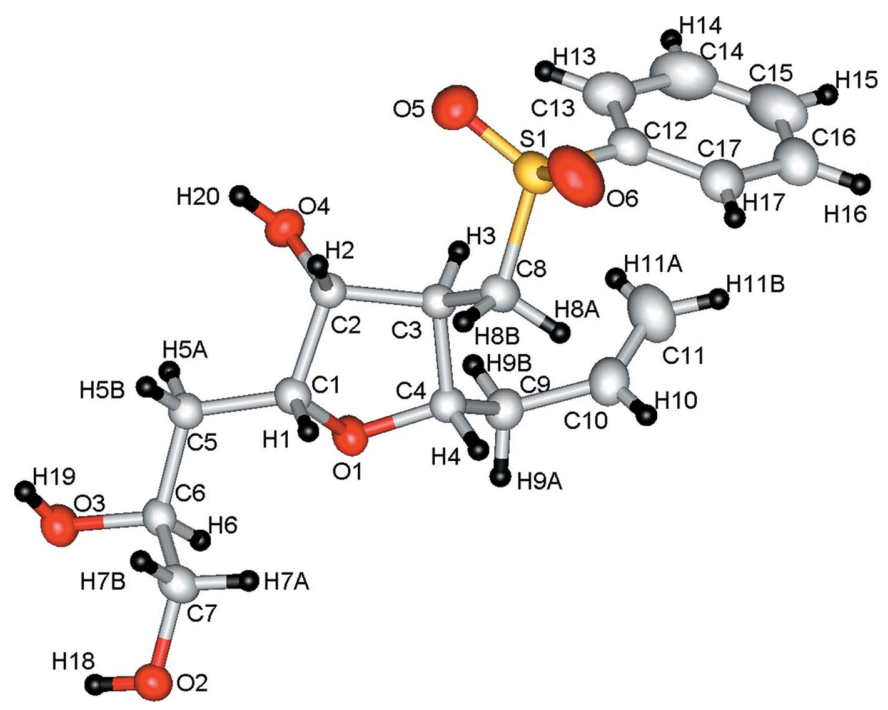

Figure 7

Single-crystal X-ray view of (XV), showing atoms $\mathrm{H} 2$ and $\mathrm{H} 3$ in a perpendicular orientation to each other. Displacement ellipsoids are drawn at the $50 \%$ probability level. 


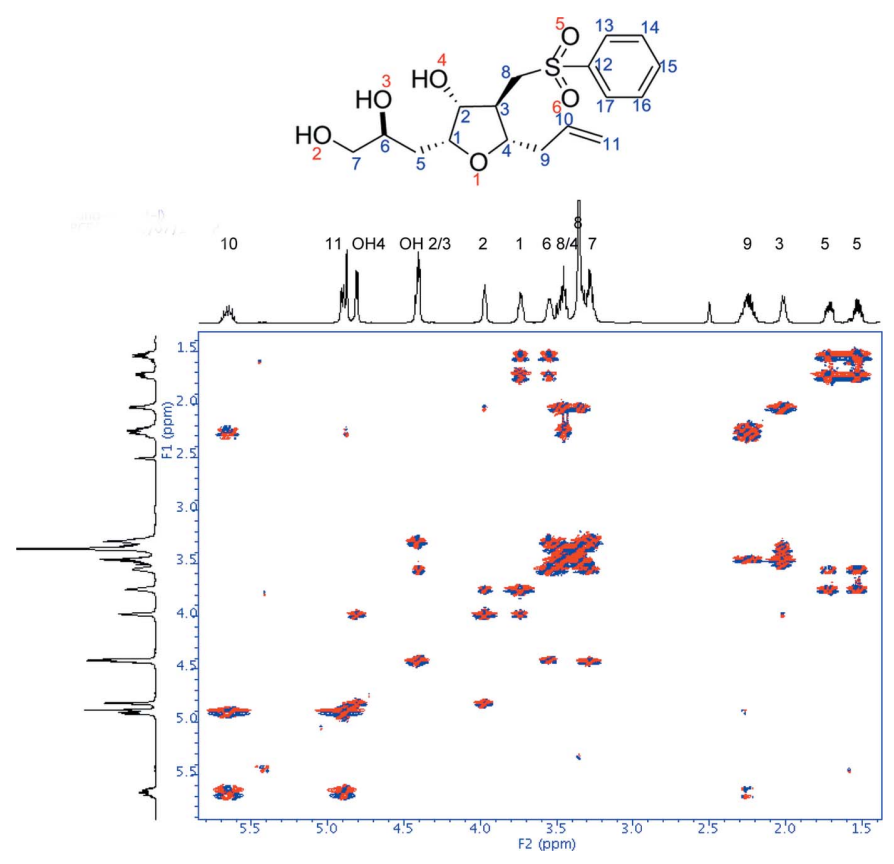

Figure 8

The 2D-COSY spectrum of (XV).

The single-crystal X-ray analysis of (XV) shows that the tetrahydrofuran ring has an envelope conformation (Fig. 7). Again the molecules pack together in the solid state with few inter- or intramolecular hydrogen bonds. The O2 and O3 hydroxy groups form an intramolecular hydrogen-bonding interaction, and also form intermolecular hydrogen-bonding interactions with atoms $\mathrm{O} 1^{\mathrm{i}}$ and $\mathrm{O} 4^{\mathrm{ii}}$ of other molecules (Table 3). Also, atom $\mathrm{O} 4$ forms an intermolecular hydrogenbonding interaction with atom $\mathrm{O} 2{ }^{\mathrm{iii}}$ of another molecule. These interactions link the molecules into two-dimensional networks, which lie parallel to the (001) plane.

We were particularly interested to see the orientation of the vicinal $\mathrm{H}$ atoms on atoms $\mathrm{C} 2$ and $\mathrm{C} 3$ of the tetrahydrofuran ring, as these two $\mathrm{H}$ atoms show an unusually weak interaction in the COSY spectrum (Fig. 8; $\mathrm{H} 2$ at 4 p.p.m. and $\mathrm{H} 3$ at 2 p.p.m.). This can happen when the $\mathrm{C}-\mathrm{H}$ bonds form a $90^{\circ}$ dihedral angle. The Karplus relationship is based on the observation that vicinal $\mathrm{H}-\mathrm{H}$ couplings will be at a maximum for $\mathrm{H}$ atoms with dihedral angles of 180 and $0^{\circ}$ (an anti or eclipsed relationship results in optimal orbital overlap) and that coupling $\left({ }^{3} J_{\mathrm{HH}}\right)$ will be minimal (near $0^{\circ}$ ) for $\mathrm{H}$ atoms that are $90^{\circ}$ from each other. Atoms $\mathrm{H} 2$ and $\mathrm{H} 3$ exhibit minimal $J$ coupling, suggesting that their $\mathrm{C}-\mathrm{H}$ bonds are nearly perpendicular to one another. The tetrahydrofuran ring with its envelope conformation facilitates this orientation of the vicinal $\mathrm{H}$ atoms. This conclusion is consistent with the molecular structure elucidated from the single-crystal X-ray diffraction data, which shows that the $\mathrm{H} 2-\mathrm{C} 2-\mathrm{C} 3-\mathrm{H} 3$ torsion angle is $-110^{\circ}$. The $\mathrm{H} 2 \cdots \mathrm{H} 3$ interatomic distance is $2.71 \AA$.

In conclusion, we have synthesized two compounds, (XII) and (XV), which have important structural implications for the Eribulin framework. We deduced the relative molecular framework of both structures through 2D-NMR experiments and conclusively proved the absolute structure of both these structures using single-crystal X-ray diffraction techniques.

\section{Acknowledgements}

We wish to thank our integrated product development (IPD) leadership team comprising of Ms Geena Malhotra, $\mathrm{Mr}$ Dharmaraj Rao and Dr Manish Gangrade for their continual support and guidance to this project. We also extend our heartfelt thanks to Professor Vedavati Puranik from the National Chemical Laboratory (NCL), Pune, India, for providing important input during the drafting of this paper.

\section{References}

Aicher, T. D., Buszek, K. R., Fang, F. G., Forsyth, C. J., Jung, S. H., Kishi, Y., Matelich, M. C., Scola, P. M., Spero, D. M. \& Yoon, S. K. (1992). J. Am. Chem. Soc. 114, 3162-3164.

Altomare, A., Cascarano, G., Giacovazzo, C., Guagliardi, A., Burla, M. C., Polidori, G. \& Camalli, M. (1994). J. Appl. Cryst. 27, 435.

Austad, B. C., et al. (2013). Synlett, 24, 6327-6332.

Brian, C. A., et al. (2013). Synlett, 24, 327-332.

Charles, E. C., Francis, G. F., Bryan, M. L., Gordon, D. W., Matthew, J. S. \& Xiaojie, Z. (2013). Synlett, 24, 323-326.

Hirata, Y. \& Uemura, D. (1986). Pure Appl. Chem. 58, 701-710.

Hiyama, T., Kimura, K. \& Nozaki, H. (1981). Tetrahedron Lett. 22 , 1037-1040.

Jin, H., Uenishi, J., Christ, W. \& Kishi, Y. (1986). J. Am. Chem. Soc. 108, 5644-5646.

Kishi, Y., Fung, F. G., Forsynth, C. J., Scola, P. M. \& Yoon, S. K. (1994). US Patent 5338865 .

Kolb, H. C., VanNieuwenhze, M. S. \& Sharpless, K. B. (1994). Chem. Rev. 94, 2483-2547.

Masamme, S., Choy, W., Peterson, J. S. \& Sita, L. R. (1985). Angew. Chem. 24, 1-76.

Parsons, S., Flack, H. D. \& Wagner, T. (2013). Acta Cryst. B69, 249 259.

Rigaku (1999). NUMABS. Rigaku Corporation, Tokyo, Japan.

Rigaku (2014). CrystalClear-SM Expert. Rigaku Corporation, Tokyo, Japan.

Rigaku (2015). CrystalStructure. Rigaku Corporation, Tokyo, Japan. Sheldrick, G. M. (2015). Acta Cryst. C71, 3-8.

Smith, J. A., Wilson, L., Azarenko, O., Zhu, X., Lewis, B. M., Littlefield, B. A. \& Jordan, M. A. (2010). Biochemistry, 49, 13311337.

Stamos, D. P. \& Kishi, Y. (1996). Tetrahedron Lett. 37, 8643-8646.

Towle, M. J., et al. (2001). Cancer Res. 61, 1013-1021.

Yang, Y. R., Kim, D. S. \& Kishi, Y. (2009). Org. Lett. 11, 45164519.

Yu, M. J., Zheng, W. \& Seletsky, B. M. (2013). Nat. Prod. Rep. 30, 1158-1164. 


\section{supporting information}

Acta Cryst. (2016). C72, 14-20 [doi:10.1107/S2053229615022305]

Structural corroboration of two important building blocks of the anticancer drug eribulin mesylate through two-dimensional NMR and single-crystal X-ray diffraction studies

\section{Srinivas Venkata Pullela, Vinod Acharya, Nagarjuna Reddy, Jayvant Harlikar, Amar Kulkarni, Rakesh Chavan, Ajay Yadav, Shuvendu Manna and Angshuman Ghosh}

Computing details

For both compounds, data collection: CrystalClear-SM Expert (Rigaku, 2014); cell refinement: CrystalClear-SM Expert (Rigaku, 2014); data reduction: CrystalClear-SM Expert (Rigaku, 2014); program(s) used to solve structure: SIR92 (Altomare et al., 1994); program(s) used to refine structure: SHELXL2014 (Sheldrick, 2015); molecular graphics: CrystalStructure (Rigaku, 2015); software used to prepare material for publication: CrystalStructure (Rigaku, 2015).

(Comp_XII) 3,4:6,7-Di-O-cyclohexylidene-D-glycero- $\alpha$-L-talo-heptopyranose methanol monosolvate

Crystal data

$\mathrm{C}_{19} \mathrm{H}_{30} \mathrm{O}_{7} \cdot \mathrm{CH}_{4} \mathrm{O}$

$M_{r}=402.48$

Orthorhombic, $P 2{ }_{1} 22_{1}$

$a=7.2240$ (18) $\AA$

$b=12.935(3) \AA$

$c=22.0691(10) \AA$

$V=2062.2(7) \AA^{3}$

$Z=4$

$F(000)=872.00$

\section{Data collection}

Rigaku XtaLAB mini diffractometer

Detector resolution: 13.653 pixels $\mathrm{mm}^{-1}$ $\omega$ scans

Absorption correction: numerical (NUMABS; Rigaku, 1999)

$T_{\min }=0.967, T_{\max }=0.980$

20377 measured reflections

\section{Refinement}

Refinement on $F^{2}$

$R\left[F^{2}>2 \sigma\left(F^{2}\right)\right]=0.037$

$w R\left(F^{2}\right)=0.100$

$S=1.08$

4735 reflections

256 parameters

0 restraints
$D_{\mathrm{x}}=1.296 \mathrm{Mg} \mathrm{m}^{-3}$

Mo $K \alpha$ radiation, $\lambda=0.71075 \AA$

Cell parameters from 6335 reflections

$\theta=3.2-27.5^{\circ}$

$\mu=0.10 \mathrm{~mm}^{-1}$

$T=293 \mathrm{~K}$

Prism, colorless

$0.20 \times 0.20 \times 0.20 \mathrm{~mm}$

4735 independent reflections

4568 reflections with $F^{2}>2.0 \sigma\left(F^{2}\right)$

$R_{\text {int }}=0.027$

$\theta_{\max }=27.5^{\circ}, \theta_{\min }=3.2^{\circ}$

$h=-9 \rightarrow 9$

$k=-16 \rightarrow 16$

$l=-28 \rightarrow 28$

Primary atom site location: structure-invariant direct methods

Secondary atom site location: difference Fourier map

Hydrogen site location: inferred from neighbouring sites

$\mathrm{H}$-atom parameters constrained 
$w=1 /\left[\sigma^{2}\left(F_{\mathrm{o}}^{2}\right)+(0.0514 P)^{2}+0.2988 P\right]$

where $P=\left(F_{\mathrm{o}}^{2}+2 F_{\mathrm{c}}^{2}\right) / 3$

$(\Delta / \sigma)_{\max }<0.001$

$\Delta \rho_{\max }=0.29 \mathrm{e} \AA^{-3}$

$\Delta \rho_{\min }=-0.29$ e $\AA^{-3}$

Special details

Geometry. All esds (except the esd in the dihedral angle between two 1.s. planes) are estimated using the full covariance matrix. The cell esds are taken into account individually in the estimation of esds in distances, angles and torsion angles; correlations between esds in cell parameters are only used when they are defined by crystal symmetry. An approximate (isotropic) treatment of cell esds is used for estimating esds involving l.s. planes.

Refinement. Refinement was performed using all reflections. The weighted R-factor (wR) and goodness of fit (S) are based on $\mathrm{F}^{2}$. R-factor (gt) are based on $\mathrm{F}$. The threshold expression of $\mathrm{F}^{2}>2.0 \operatorname{sigma}\left(\mathrm{F}^{2}\right)$ is used only for calculating $\mathrm{R}$ factor (gt).

Neutral-atom scattering factors were taken from international tables for crystallography, Vol. C, Table 6.1.1.4. Anomalous dispersion effects were included in Fcalc (Ibers \& Hamilton, 1964); the values for ? $\mathrm{f}^{\prime}$ and ? $\mathrm{f}^{\prime \prime}$ were extracted from international tables of crystallography (Creagh \& McAuley, 1992). The values for the mass attenuation coefficients are those of Creagh and Hubbell.

Creagh, D. C. \& Hubbell, J.H..; "International Tables for Crystallography", Vol C, (A.J.C. Wilson, ed.), Kluwer Academic Publishers, Boston, Table 4.2.4.3, pages 200-206 (1992).

Creagh, D. C. \& McAuley, W. J. (1992). International Tables for Crystallography, (A. J. C. Wilson, ed.), Kluwer

Academic Publishers, Boston, Vol C, Table 4.2.6.8, 219-222.

Ibers, J. A. \& Hamilton, W. C. (1964). Acta Cryst. 17, 781-782.

Fractional atomic coordinates and isotropic or equivalent isotropic displacement parameters $\left(\AA^{2}\right)$

\begin{tabular}{lllll}
\hline & $x$ & $y$ & $z$ & $U_{\text {iso }} * / U_{\text {eq }}$ \\
\hline O1 & $0.35295(19)$ & $0.58282(12)$ & $0.48548(6)$ & $0.0371(3)$ \\
O2 & $0.3077(2)$ & $0.72969(12)$ & $0.42698(7)$ & $0.0421(3)$ \\
H21 & 0.2018 & 0.7108 & 0.4194 & $0.050^{*}$ \\
O3 & $0.6894(2)$ & $0.72168(11)$ & $0.39171(6)$ & $0.0384(3)$ \\
H22 & 0.6789 & 0.7848 & 0.3911 & $0.046^{*}$ \\
O4 & $0.75860(19)$ & $0.51822(10)$ & $0.42770(6)$ & $0.0311(3)$ \\
O5 & $0.6597(2)$ & $0.43865(10)$ & $0.51248(7)$ & $0.0382(3)$ \\
O6 & $0.19472(19)$ & $0.55968(11)$ & $0.60599(6)$ & $0.0336(3)$ \\
O7 & $0.3195(2)$ & $0.46408(14)$ & $0.68318(7)$ & $0.0471(4)$ \\
O8 & $0.5386(3)$ & $0.8094(4)$ & $0.65156(10)$ & $0.1275(16)$ \\
H23 & 0.4296 & 0.8074 & 0.6412 & $0.153^{*}$ \\
C1 & $0.4200(3)$ & $0.64349(14)$ & $0.43614(8)$ & $0.0294(4)$ \\
H1 & 0.4191 & 0.6011 & 0.3993 & $0.035^{*}$ \\
C2 & $0.6160(3)$ & $0.68268(13)$ & $0.44707(8)$ & $0.0283(4)$ \\
H2 & 0.6111 & 0.7392 & 0.4766 & $0.034^{*}$ \\
C3 & $0.7420(2)$ & $0.59962(13)$ & $0.47104(8)$ & $0.0273(4)$ \\
H3 & 0.8640 & 0.6284 & 0.4806 & $0.033^{*}$ \\
C4 & $0.6584(3)$ & $0.54600(13)$ & $0.52731(8)$ & $0.0280(4)$ \\
H4 & 0.7365 & 0.5587 & 0.5629 & $0.034^{*}$ \\
C5 & $0.4611(3)$ & $0.58198(14)$ & $0.53966(8)$ & $0.0279(4)$ \\
H5 & 0.4647 & 0.6520 & 0.5565 & $0.033^{*}$ \\
C6 & $0.3620(2)$ & $0.51148(14)$ & $0.58383(8)$ & $0.0287(4)$ \\
H6 & 0.3316 & 0.4459 & 0.5639 & $0.034^{*}$ \\
C7 & $0.4637(3)$ & $0.49056(17)$ & $0.64252(9)$ & $0.0351(4)$ \\
& & &
\end{tabular}




\begin{tabular}{|c|c|c|c|c|}
\hline H7A & 0.5508 & 0.4340 & 0.6379 & $0.042 *$ \\
\hline H7B & 0.5297 & 0.5515 & 0.6562 & $0.042 *$ \\
\hline $\mathrm{C} 8$ & $0.1523(3)$ & $0.51299(15)$ & $0.66350(9)$ & 0.0331 (4) \\
\hline C9 & $0.0938(4)$ & $0.5960(2)$ & $0.70757(11)$ & $0.0524(6)$ \\
\hline H9A & -0.0106 & 0.6337 & 0.6909 & $0.063 *$ \\
\hline H9B & 0.1948 & 0.6444 & 0.7133 & $0.063 *$ \\
\hline $\mathrm{C} 10$ & $0.0394(5)$ & $0.5495(2)$ & $0.76878(12)$ & $0.0625(7)$ \\
\hline $\mathrm{H} 10 \mathrm{~A}$ & 0.1474 & 0.5182 & 0.7874 & $0.075^{*}$ \\
\hline H10B & -0.0039 & 0.6042 & 0.7953 & $0.075^{*}$ \\
\hline $\mathrm{C} 11$ & $-0.1116(4)$ & $0.4685(3)$ & $0.76198(12)$ & 0.0617 (7) \\
\hline H11A & -0.1374 & 0.4377 & 0.8011 & $0.074 *$ \\
\hline H11B & -0.2241 & 0.5012 & 0.7476 & $0.074 *$ \\
\hline $\mathrm{C} 12$ & $-0.0527(4)$ & $0.3850(2)$ & $0.71778(12)$ & $0.0530(6)$ \\
\hline H12A & -0.1545 & 0.3372 & 0.7117 & $0.064 *$ \\
\hline H12B & 0.0502 & 0.3466 & 0.7348 & $0.064^{*}$ \\
\hline $\mathrm{C} 13$ & $0.0050(3)$ & $0.43058(18)$ & $0.65660(10)$ & $0.0418(5)$ \\
\hline H13A & 0.0519 & 0.3757 & 0.6309 & $0.050^{*}$ \\
\hline H13B & -0.1026 & 0.4603 & 0.6369 & $0.050^{*}$ \\
\hline $\mathrm{C} 14$ & $0.7801(3)$ & $0.42518(14)$ & $0.46154(8)$ & 0.0305 (4) \\
\hline $\mathrm{C} 15$ & $0.7147(3)$ & $0.33586(16)$ & $0.42330(11)$ & $0.0423(5)$ \\
\hline H15A & 0.5917 & 0.3507 & 0.4079 & $0.051^{*}$ \\
\hline H15B & 0.7071 & 0.2742 & 0.4482 & $0.051^{*}$ \\
\hline $\mathrm{C} 16$ & $0.8454(4)$ & $0.31621(18)$ & $0.37032(11)$ & $0.0475(5)$ \\
\hline H16A & 0.8046 & 0.2554 & 0.3484 & $0.057^{*}$ \\
\hline H16B & 0.8408 & 0.3746 & 0.3428 & $0.057^{*}$ \\
\hline $\mathrm{C} 17$ & $1.0433(4)$ & $0.3003(2)$ & $0.39150(13)$ & $0.0526(6)$ \\
\hline H17A & 1.1235 & 0.2917 & 0.3566 & $0.063^{*}$ \\
\hline H17B & 1.0507 & 0.2379 & 0.4158 & $0.063^{*}$ \\
\hline $\mathrm{C} 18$ & $1.1088(3)$ & $0.3921(2)$ & $0.42881(12)$ & $0.0478(5)$ \\
\hline $\mathrm{H} 18 \mathrm{~A}$ & 1.1127 & 0.4532 & 0.4034 & $0.057^{*}$ \\
\hline H18B & 1.2330 & 0.3789 & 0.4436 & $0.057^{*}$ \\
\hline C19 & $0.9804(3)$ & $0.41131(17)$ & $0.48222(10)$ & 0.0384 (4) \\
\hline H19A & 1.0204 & 0.4728 & 0.5037 & $0.046^{*}$ \\
\hline H19B & 0.9877 & 0.3534 & 0.5100 & $0.046^{*}$ \\
\hline $\mathrm{C} 20$ & $0.5497(5)$ & $0.8009(5)$ & $0.70985(16)$ & $0.1046(17)$ \\
\hline $\mathrm{H} 20 \mathrm{~A}$ & 0.5570 & 0.8684 & 0.7277 & $0.126^{*}$ \\
\hline $\mathrm{H} 20 \mathrm{~B}$ & 0.6583 & 0.7620 & 0.7203 & $0.126^{*}$ \\
\hline $\mathrm{H} 20 \mathrm{C}$ & 0.4419 & 0.7658 & 0.7249 & $0.126^{*}$ \\
\hline
\end{tabular}

Atomic displacement parameters $\left(\AA^{2}\right)$

\begin{tabular}{lllllll}
\hline & $U^{11}$ & $U^{22}$ & $U^{33}$ & $U^{12}$ & $U^{13}$ & $U^{23}$ \\
\hline O1 & $0.0301(6)$ & $0.0475(8)$ & $0.0337(7)$ & $-0.0081(6)$ & $-0.0046(6)$ & $0.0125(6)$ \\
O2 & $0.0391(8)$ & $0.0433(8)$ & $0.0439(8)$ & $0.0115(7)$ & $-0.0042(7)$ & $0.0044(6)$ \\
O3 & $0.0463(8)$ & $0.0315(6)$ & $0.0373(7)$ & $0.0007(6)$ & $0.0088(7)$ & $0.0103(6)$ \\
O4 & $0.0377(7)$ & $0.0272(6)$ & $0.0283(6)$ & $0.0048(5)$ & $0.0037(5)$ & $-0.0007(5)$ \\
O5 & $0.0444(8)$ & $0.0265(6)$ & $0.0436(8)$ & $0.0037(6)$ & $0.0168(7)$ & $0.0042(5)$ \\
O6 & $0.0306(6)$ & $0.0381(7)$ & $0.0321(7)$ & $0.0063(6)$ & $0.0068(6)$ & $0.0102(5)$
\end{tabular}


supporting information

\begin{tabular}{lllllll} 
O7 & $0.0331(7)$ & $0.0700(11)$ & $0.0382(8)$ & $0.0060(7)$ & $0.0031(6)$ & $0.0235(8)$ \\
O8 & $0.0373(10)$ & $0.296(5)$ & $0.0495(12)$ & $0.015(2)$ & $0.0035(10)$ & $0.006(2)$ \\
C1 & $0.0320(9)$ & $0.0305(8)$ & $0.0257(8)$ & $0.0019(7)$ & $-0.0004(7)$ & $0.0011(7)$ \\
C2 & $0.0324(9)$ & $0.0241(8)$ & $0.0284(8)$ & $-0.0005(7)$ & $0.0029(7)$ & $0.0015(6)$ \\
C3 & $0.0261(8)$ & $0.0267(8)$ & $0.0291(8)$ & $-0.0006(7)$ & $0.0005(7)$ & $-0.0013(7)$ \\
C4 & $0.0295(8)$ & $0.0280(8)$ & $0.0266(8)$ & $0.0014(7)$ & $0.0000(7)$ & $0.0005(6)$ \\
C5 & $0.0283(8)$ & $0.0279(8)$ & $0.0273(8)$ & $0.0002(7)$ & $0.0017(7)$ & $0.0012(7)$ \\
C6 & $0.0271(8)$ & $0.0297(8)$ & $0.0292(8)$ & $-0.0003(7)$ & $0.0036(7)$ & $0.0022(7)$ \\
C7 & $0.0291(9)$ & $0.0412(10)$ & $0.0352(9)$ & $0.0028(8)$ & $0.0016(8)$ & $0.0062(8)$ \\
C8 & $0.0313(9)$ & $0.0379(9)$ & $0.0302(9)$ & $0.0032(8)$ & $0.0048(7)$ & $0.0088(7)$ \\
C9 & $0.0696(17)$ & $0.0458(12)$ & $0.0418(12)$ & $-0.0032(12)$ & $0.0181(12)$ & $-0.0015(10)$ \\
C10 & $0.0811(19)$ & $0.0695(17)$ & $0.0369(12)$ & $-0.0062(15)$ & $0.0208(13)$ & $-0.0041(11)$ \\
C11 & $0.0542(14)$ & $0.088(2)$ & $0.0426(12)$ & $-0.0018(14)$ & $0.0173(12)$ & $0.0176(13)$ \\
C12 & $0.0490(13)$ & $0.0579(15)$ & $0.0521(13)$ & $-0.0116(11)$ & $0.0022(11)$ & $0.0207(11)$ \\
C13 & $0.0395(11)$ & $0.0465(11)$ & $0.0396(11)$ & $-0.0043(9)$ & $0.0002(9)$ & $0.0080(9)$ \\
C14 & $0.0331(9)$ & $0.0267(8)$ & $0.0319(9)$ & $0.0023(7)$ & $0.0051(7)$ & $0.0025(7)$ \\
C15 & $0.0408(11)$ & $0.0328(10)$ & $0.0534(12)$ & $-0.0055(8)$ & $0.0008(10)$ & $-0.0082(9)$ \\
C16 & $0.0569(14)$ & $0.0408(11)$ & $0.0450(12)$ & $-0.0035(11)$ & $0.0005(11)$ & $-0.0151(9)$ \\
C17 & $0.0536(14)$ & $0.0463(13)$ & $0.0581(15)$ & $0.0107(11)$ & $0.0114(12)$ & $-0.0125(11)$ \\
C18 & $0.0335(10)$ & $0.0513(13)$ & $0.0585(14)$ & $0.0060(9)$ & $0.0055(10)$ & $-0.0108(11)$ \\
C19 & $0.0373(10)$ & $0.0378(10)$ & $0.0401(10)$ & $0.0094(8)$ & $-0.0041(9)$ & $-0.0040(8)$ \\
C20 & $0.0575(19)$ & $0.192(5)$ & $0.064(2)$ & $-0.003(3)$ & $-0.0071(17)$ & $-0.044(3)$ \\
& & & & & & \\
\hline
\end{tabular}

Geometric parameters $\left(\AA,{ }^{\circ}\right)$

\begin{tabular}{llll}
\hline $\mathrm{O} 1-\mathrm{C} 1$ & $1.427(2)$ & $\mathrm{C} 9-\mathrm{H} 9 \mathrm{~A}$ & 0.9700 \\
$\mathrm{O} 1-\mathrm{C} 5$ & $1.428(2)$ & $\mathrm{C} 9-\mathrm{H} 9 \mathrm{~B}$ & 0.9700 \\
$\mathrm{O} 2-\mathrm{C} 1$ & $1.394(2)$ & $\mathrm{C} 10-\mathrm{C} 11$ & $1.520(4)$ \\
$\mathrm{O} 2-\mathrm{H} 21$ & 0.8200 & $\mathrm{C} 10-\mathrm{H} 10 \mathrm{~A}$ & 0.9700 \\
$\mathrm{O} 3-\mathrm{C} 2$ & $1.424(2)$ & $\mathrm{C} 10-\mathrm{H} 10 \mathrm{~B}$ & 0.9700 \\
$\mathrm{O} 3-\mathrm{H} 22$ & 0.8200 & $\mathrm{C} 11-\mathrm{C} 12$ & $1.517(4)$ \\
$\mathrm{O} 4-\mathrm{C} 14$ & $1.425(2)$ & $\mathrm{C} 11-\mathrm{H} 11 \mathrm{~A}$ & 0.9700 \\
$\mathrm{O} 4-\mathrm{C} 3$ & $1.428(2)$ & $\mathrm{C} 11-\mathrm{H} 11 \mathrm{~B}$ & 0.9700 \\
$\mathrm{O} 5-\mathrm{C} 4$ & $1.427(2)$ & $\mathrm{C} 12-\mathrm{C} 13$ & $1.531(3)$ \\
$\mathrm{O} 5-\mathrm{C} 14$ & $1.432(2)$ & $\mathrm{C} 12-\mathrm{H} 12 \mathrm{~A}$ & 0.9700 \\
$\mathrm{O} 6-\mathrm{C} 8$ & $1.439(2)$ & $\mathrm{C} 12-\mathrm{H} 12 \mathrm{~B}$ & 0.9700 \\
$\mathrm{O} 6-\mathrm{C} 6$ & $1.445(2)$ & $\mathrm{C} 13-\mathrm{H} 13 \mathrm{~A}$ & 0.9700 \\
$\mathrm{O} 7-\mathrm{C} 7$ & $1.417(2)$ & $\mathrm{C} 13-\mathrm{H} 13 \mathrm{~B}$ & 0.9700 \\
$\mathrm{O} 7-\mathrm{C} 8$ & $1.431(2)$ & $\mathrm{C} 14-\mathrm{C} 15$ & $1.507(3)$ \\
$\mathrm{O} 8-\mathrm{C} 20$ & $1.294(4)$ & $\mathrm{C} 14-\mathrm{C} 19$ & $1.528(3)$ \\
$\mathrm{O} 8-\mathrm{H} 23$ & 0.8200 & $\mathrm{C} 15-\mathrm{C} 16$ & $1.524(3)$ \\
$\mathrm{C} 1-\mathrm{C} 2$ & $1.523(3)$ & $\mathrm{C} 15-\mathrm{H} 15 \mathrm{~A}$ & 0.9700 \\
$\mathrm{C} 1-\mathrm{H} 1$ & 0.9800 & $\mathrm{C} 15-\mathrm{H} 15 \mathrm{~B}$ & 0.9700 \\
$\mathrm{C} 2-\mathrm{C} 3$ & $1.504(2)$ & $\mathrm{C} 16-\mathrm{C} 17$ & $1.518(4)$ \\
$\mathrm{C} 2-\mathrm{H} 2$ & 0.9800 & $\mathrm{C} 16-\mathrm{H} 16 \mathrm{~A}$ & 0.9700 \\
$\mathrm{C} 3-\mathrm{C} 4$ & $1.545(2)$ & $\mathrm{C} 16-\mathrm{H} 16 \mathrm{~B}$ & 0.9700 \\
$\mathrm{C} 3-\mathrm{H} 3$ & 0.9800 & $\mathrm{C} 17-\mathrm{C} 18$ & $1.520(3)$ \\
$\mathrm{C} 4-\mathrm{C} 5$ & $1.524(3)$ & $\mathrm{C} 17-\mathrm{H} 17 \mathrm{~A}$ & 0.9700
\end{tabular}




\begin{tabular}{|c|c|c|c|}
\hline $\mathrm{C} 4-\mathrm{H} 4$ & 0.9800 & C17-H17B & 0.9700 \\
\hline $\mathrm{C} 5-\mathrm{C} 6$ & $1.515(2)$ & $\mathrm{C} 18-\mathrm{C} 19$ & $1.520(3)$ \\
\hline $\mathrm{C} 5-\mathrm{H} 5$ & 0.9800 & C18-H18A & 0.9700 \\
\hline $\mathrm{C} 6-\mathrm{C} 7$ & $1.513(3)$ & $\mathrm{C} 18-\mathrm{H} 18 \mathrm{~B}$ & 0.9700 \\
\hline $\mathrm{C} 6-\mathrm{H} 6$ & 0.9800 & C19-H19A & 0.9700 \\
\hline C7-H7A & 0.9700 & C19-H19B & 0.9700 \\
\hline C7-H7B & 0.9700 & $\mathrm{C} 20-\mathrm{H} 20 \mathrm{~A}$ & 0.9600 \\
\hline $\mathrm{C} 8-\mathrm{C} 9$ & $1.509(3)$ & $\mathrm{C} 20-\mathrm{H} 20 \mathrm{~B}$ & 0.9600 \\
\hline $\mathrm{C} 8-\mathrm{C} 13$ & $1.514(3)$ & $\mathrm{C} 20-\mathrm{H} 20 \mathrm{C}$ & 0.9600 \\
\hline $\mathrm{C} 9-\mathrm{C} 10$ & $1.530(3)$ & & \\
\hline $\mathrm{C} 1-\mathrm{O} 1-\mathrm{C} 5$ & $117.22(14)$ & $\mathrm{C} 9-\mathrm{C} 10-\mathrm{H} 10 \mathrm{~A}$ & 109.3 \\
\hline $\mathrm{C} 1-\mathrm{O} 2-\mathrm{H} 21$ & 109.5 & $\mathrm{C} 11-\mathrm{C} 10-\mathrm{H} 10 \mathrm{~B}$ & 109.3 \\
\hline $\mathrm{C} 2-\mathrm{O} 3-\mathrm{H} 22$ & 109.5 & C9- $\mathrm{C} 10-\mathrm{H} 10 \mathrm{~B}$ & 109.3 \\
\hline $\mathrm{C} 14-\mathrm{O} 4-\mathrm{C} 3$ & $106.31(13)$ & $\mathrm{H} 10 \mathrm{~A}-\mathrm{C} 10-\mathrm{H} 10 \mathrm{~B}$ & 108.0 \\
\hline $\mathrm{C} 4-\mathrm{O} 5-\mathrm{C} 14$ & $107.60(14)$ & $\mathrm{C} 12-\mathrm{C} 11-\mathrm{C} 10$ & $110.7(2)$ \\
\hline $\mathrm{C} 8-\mathrm{O} 6-\mathrm{C} 6$ & $107.20(13)$ & $\mathrm{C} 12-\mathrm{C} 11-\mathrm{H} 11 \mathrm{~A}$ & 109.5 \\
\hline $\mathrm{C} 7-\mathrm{O} 7-\mathrm{C} 8$ & $108.75(14)$ & $\mathrm{C} 10-\mathrm{C} 11-\mathrm{H} 11 \mathrm{~A}$ & 109.5 \\
\hline $\mathrm{C} 20-\mathrm{O} 8-\mathrm{H} 23$ & 109.5 & $\mathrm{C} 12-\mathrm{C} 11-\mathrm{H} 11 \mathrm{~B}$ & 109.5 \\
\hline $\mathrm{O} 2-\mathrm{C} 1-\mathrm{O} 1$ & $110.68(15)$ & $\mathrm{C} 10-\mathrm{C} 11-\mathrm{H} 11 \mathrm{~B}$ & 109.5 \\
\hline $\mathrm{O} 2-\mathrm{C} 1-\mathrm{C} 2$ & $107.32(16)$ & $\mathrm{H} 11 \mathrm{~A}-\mathrm{C} 11-\mathrm{H} 11 \mathrm{~B}$ & 108.1 \\
\hline $\mathrm{O} 1-\mathrm{C} 1-\mathrm{C} 2$ & $112.19(15)$ & $\mathrm{C} 11-\mathrm{C} 12-\mathrm{C} 13$ & $111.6(2)$ \\
\hline $\mathrm{O} 2-\mathrm{C} 1-\mathrm{H} 1$ & 108.9 & $\mathrm{C} 11-\mathrm{C} 12-\mathrm{H} 12 \mathrm{~A}$ & 109.3 \\
\hline $\mathrm{O} 1-\mathrm{C} 1-\mathrm{H} 1$ & 108.9 & $\mathrm{C} 13-\mathrm{C} 12-\mathrm{H} 12 \mathrm{~A}$ & 109.3 \\
\hline $\mathrm{C} 2-\mathrm{C} 1-\mathrm{H} 1$ & 108.9 & $\mathrm{C} 11-\mathrm{C} 12-\mathrm{H} 12 \mathrm{~B}$ & 109.3 \\
\hline $\mathrm{O} 3-\mathrm{C} 2-\mathrm{C} 3$ & $109.24(15)$ & $\mathrm{C} 13-\mathrm{C} 12-\mathrm{H} 12 \mathrm{~B}$ & 109.3 \\
\hline $\mathrm{O} 3-\mathrm{C} 2-\mathrm{C} 1$ & $109.16(15)$ & $\mathrm{H} 12 \mathrm{~A}-\mathrm{C} 12-\mathrm{H} 12 \mathrm{~B}$ & 108.0 \\
\hline $\mathrm{C} 3-\mathrm{C} 2-\mathrm{C} 1$ & $112.36(15)$ & $\mathrm{C} 8-\mathrm{C} 13-\mathrm{C} 12$ & $111.97(19)$ \\
\hline $\mathrm{O} 3-\mathrm{C} 2-\mathrm{H} 2$ & 108.7 & $\mathrm{C} 8-\mathrm{C} 13-\mathrm{H} 13 \mathrm{~A}$ & 109.2 \\
\hline $\mathrm{C} 3-\mathrm{C} 2-\mathrm{H} 2$ & 108.7 & $\mathrm{C} 12-\mathrm{C} 13-\mathrm{H} 13 \mathrm{~A}$ & 109.2 \\
\hline $\mathrm{C} 1-\mathrm{C} 2-\mathrm{H} 2$ & 108.7 & $\mathrm{C} 8-\mathrm{C} 13-\mathrm{H} 13 \mathrm{~B}$ & 109.2 \\
\hline $\mathrm{O} 4-\mathrm{C} 3-\mathrm{C} 2$ & $110.01(14)$ & $\mathrm{C} 12-\mathrm{C} 13-\mathrm{H} 13 \mathrm{~B}$ & 109.2 \\
\hline $\mathrm{O} 4-\mathrm{C} 3-\mathrm{C} 4$ & $103.90(13)$ & $\mathrm{H} 13 \mathrm{~A}-\mathrm{C} 13-\mathrm{H} 13 \mathrm{~B}$ & 107.9 \\
\hline $\mathrm{C} 2-\mathrm{C} 3-\mathrm{C} 4$ & $111.54(15)$ & $\mathrm{O} 4-\mathrm{C} 14-\mathrm{O} 5$ & $104.05(14)$ \\
\hline $\mathrm{O} 4-\mathrm{C} 3-\mathrm{H} 3$ & 110.4 & $\mathrm{O} 4-\mathrm{C} 14-\mathrm{C} 15$ & $108.65(16)$ \\
\hline $\mathrm{C} 2-\mathrm{C} 3-\mathrm{H} 3$ & 110.4 & $\mathrm{O} 5-\mathrm{C} 14-\mathrm{C} 15$ & $110.03(17)$ \\
\hline $\mathrm{C} 4-\mathrm{C} 3-\mathrm{H} 3$ & 110.4 & $\mathrm{O} 4-\mathrm{C} 14-\mathrm{C} 19$ & $111.03(16)$ \\
\hline $\mathrm{O} 5-\mathrm{C} 4-\mathrm{C} 5$ & $110.13(15)$ & $\mathrm{O} 5-\mathrm{C} 14-\mathrm{C} 19$ & $110.79(16)$ \\
\hline $\mathrm{O} 5-\mathrm{C} 4-\mathrm{C} 3$ & $104.48(14)$ & $\mathrm{C} 15-\mathrm{C} 14-\mathrm{C} 19$ & $111.98(17)$ \\
\hline $\mathrm{C} 5-\mathrm{C} 4-\mathrm{C} 3$ & $111.83(14)$ & $\mathrm{C} 14-\mathrm{C} 15-\mathrm{C} 16$ & $111.30(18)$ \\
\hline $\mathrm{O} 5-\mathrm{C} 4-\mathrm{H} 4$ & 110.1 & $\mathrm{C} 14-\mathrm{C} 15-\mathrm{H} 15 \mathrm{~A}$ & 109.4 \\
\hline $\mathrm{C} 5-\mathrm{C} 4-\mathrm{H} 4$ & 110.1 & $\mathrm{C} 16-\mathrm{C} 15-\mathrm{H} 15 \mathrm{~A}$ & 109.4 \\
\hline $\mathrm{C} 3-\mathrm{C} 4-\mathrm{H} 4$ & 110.1 & $\mathrm{C} 14-\mathrm{C} 15-\mathrm{H} 15 \mathrm{~B}$ & 109.4 \\
\hline $\mathrm{O} 1-\mathrm{C} 5-\mathrm{C} 6$ & $106.55(15)$ & $\mathrm{C} 16-\mathrm{C} 15-\mathrm{H} 15 \mathrm{~B}$ & 109.4 \\
\hline $\mathrm{O} 1-\mathrm{C} 5-\mathrm{C} 4$ & $111.36(14)$ & $\mathrm{H} 15 \mathrm{~A}-\mathrm{C} 15-\mathrm{H} 15 \mathrm{~B}$ & 108.0 \\
\hline $\mathrm{C} 6-\mathrm{C} 5-\mathrm{C} 4$ & $111.91(15)$ & $\mathrm{C} 17-\mathrm{C} 16-\mathrm{C} 15$ & $111.7(2)$ \\
\hline $\mathrm{O} 1-\mathrm{C} 5-\mathrm{H} 5$ & 109.0 & $\mathrm{C} 17-\mathrm{C} 16-\mathrm{H} 16 \mathrm{~A}$ & 109.3 \\
\hline $\mathrm{C} 6-\mathrm{C} 5-\mathrm{H} 5$ & 109.0 & $\mathrm{C} 15-\mathrm{C} 16-\mathrm{H} 16 \mathrm{~A}$ & 109.3 \\
\hline
\end{tabular}




\begin{tabular}{|c|c|c|c|}
\hline $\mathrm{C} 4-\mathrm{C} 5-\mathrm{H} 5$ & 109.0 & $\mathrm{C} 17-\mathrm{C} 16-\mathrm{H} 16 \mathrm{~B}$ & 109.3 \\
\hline $\mathrm{O} 6-\mathrm{C} 6-\mathrm{C} 7$ & $101.16(14)$ & $\mathrm{C} 15-\mathrm{C} 16-\mathrm{H} 16 \mathrm{~B}$ & 109.3 \\
\hline $\mathrm{O} 6-\mathrm{C} 6-\mathrm{C} 5$ & $110.69(14)$ & $\mathrm{H} 16 \mathrm{~A}-\mathrm{C} 16-\mathrm{H} 16 \mathrm{~B}$ & 107.9 \\
\hline $\mathrm{C} 7-\mathrm{C} 6-\mathrm{C} 5$ & $115.41(16)$ & $\mathrm{C} 16-\mathrm{C} 17-\mathrm{C} 18$ & $110.74(19)$ \\
\hline $\mathrm{O} 6-\mathrm{C} 6-\mathrm{H} 6$ & 109.8 & $\mathrm{C} 16-\mathrm{C} 17-\mathrm{H} 17 \mathrm{~A}$ & 109.5 \\
\hline $\mathrm{C} 7-\mathrm{C} 6-\mathrm{H} 6$ & 109.8 & $\mathrm{C} 18-\mathrm{C} 17-\mathrm{H} 17 \mathrm{~A}$ & 109.5 \\
\hline $\mathrm{C} 5-\mathrm{C} 6-\mathrm{H} 6$ & 109.8 & $\mathrm{C} 16-\mathrm{C} 17-\mathrm{H} 17 \mathrm{~B}$ & 109.5 \\
\hline $\mathrm{O} 7-\mathrm{C} 7-\mathrm{C} 6$ & $103.20(15)$ & $\mathrm{C} 18-\mathrm{C} 17-\mathrm{H} 17 \mathrm{~B}$ & 109.5 \\
\hline $\mathrm{O} 7-\mathrm{C} 7-\mathrm{H} 7 \mathrm{~A}$ & 111.1 & $\mathrm{H} 17 \mathrm{~A}-\mathrm{C} 17-\mathrm{H} 17 \mathrm{~B}$ & 108.1 \\
\hline $\mathrm{C} 6-\mathrm{C} 7-\mathrm{H} 7 \mathrm{~A}$ & 111.1 & $\mathrm{C} 17-\mathrm{C} 18-\mathrm{C} 19$ & $111.0(2)$ \\
\hline $\mathrm{O} 7-\mathrm{C} 7-\mathrm{H} 7 \mathrm{~B}$ & 111.1 & $\mathrm{C} 17-\mathrm{C} 18-\mathrm{H} 18 \mathrm{~A}$ & 109.4 \\
\hline $\mathrm{C} 6-\mathrm{C} 7-\mathrm{H} 7 \mathrm{~B}$ & 111.1 & $\mathrm{C} 19-\mathrm{C} 18-\mathrm{H} 18 \mathrm{~A}$ & 109.4 \\
\hline $\mathrm{H} 7 \mathrm{~A}-\mathrm{C} 7-\mathrm{H} 7 \mathrm{~B}$ & 109.1 & $\mathrm{C} 17-\mathrm{C} 18-\mathrm{H} 18 \mathrm{~B}$ & 109.4 \\
\hline $\mathrm{O} 7-\mathrm{C} 8-\mathrm{O} 6$ & $105.87(14)$ & $\mathrm{C} 19-\mathrm{C} 18-\mathrm{H} 18 \mathrm{~B}$ & 109.4 \\
\hline $\mathrm{O} 7-\mathrm{C} 8-\mathrm{C} 9$ & $110.8(2)$ & $\mathrm{H} 18 \mathrm{~A}-\mathrm{C} 18-\mathrm{H} 18 \mathrm{~B}$ & 108.0 \\
\hline $\mathrm{O} 6-\mathrm{C} 8-\mathrm{C} 9$ & $109.25(17)$ & $\mathrm{C} 18-\mathrm{C} 19-\mathrm{C} 14$ & $111.43(18)$ \\
\hline $\mathrm{O} 7-\mathrm{C} 8-\mathrm{C} 13$ & $108.20(17)$ & $\mathrm{C} 18-\mathrm{C} 19-\mathrm{H} 19 \mathrm{~A}$ & 109.3 \\
\hline $\mathrm{O} 6-\mathrm{C} 8-\mathrm{C} 13$ & $110.89(16)$ & $\mathrm{C} 14-\mathrm{C} 19-\mathrm{H} 19 \mathrm{~A}$ & 109.3 \\
\hline $\mathrm{C} 9-\mathrm{C} 8-\mathrm{C} 13$ & $111.64(18)$ & $\mathrm{C} 18-\mathrm{C} 19-\mathrm{H} 19 \mathrm{~B}$ & 109.3 \\
\hline $\mathrm{C} 8-\mathrm{C} 9-\mathrm{C} 10$ & $111.2(2)$ & $\mathrm{C} 14-\mathrm{C} 19-\mathrm{H} 19 \mathrm{~B}$ & 109.3 \\
\hline $\mathrm{C} 8-\mathrm{C} 9-\mathrm{H} 9 \mathrm{~A}$ & 109.4 & $\mathrm{H} 19 \mathrm{~A}-\mathrm{C} 19-\mathrm{H} 19 \mathrm{~B}$ & 108.0 \\
\hline $\mathrm{C} 10-\mathrm{C} 9-\mathrm{H} 9 \mathrm{~A}$ & 109.4 & $\mathrm{O} 8-\mathrm{C} 20-\mathrm{H} 20 \mathrm{~A}$ & 109.5 \\
\hline $\mathrm{C} 8-\mathrm{C} 9-\mathrm{H} 9 \mathrm{~B}$ & 109.4 & $\mathrm{O} 8-\mathrm{C} 20-\mathrm{H} 20 \mathrm{~B}$ & 109.5 \\
\hline $\mathrm{C} 10-\mathrm{C} 9-\mathrm{H} 9 \mathrm{~B}$ & 109.4 & $\mathrm{H} 20 \mathrm{~A}-\mathrm{C} 20-\mathrm{H} 20 \mathrm{~B}$ & 109.5 \\
\hline $\mathrm{H} 9 \mathrm{~A}-\mathrm{C} 9-\mathrm{H} 9 \mathrm{~B}$ & 108.0 & $\mathrm{O} 8-\mathrm{C} 20-\mathrm{H} 20 \mathrm{C}$ & 109.5 \\
\hline $\mathrm{C} 11-\mathrm{C} 10-\mathrm{C} 9$ & $111.6(2)$ & $\mathrm{H} 20 \mathrm{~A}-\mathrm{C} 20-\mathrm{H} 20 \mathrm{C}$ & 109.5 \\
\hline $\mathrm{C} 11-\mathrm{C} 10-\mathrm{H} 10 \mathrm{~A}$ & 109.3 & $\mathrm{H} 20 \mathrm{~B}-\mathrm{C} 20-\mathrm{H} 20 \mathrm{C}$ & 109.5 \\
\hline $\mathrm{C} 5-\mathrm{O} 1-\mathrm{C} 1-\mathrm{O} 2$ & $-109.98(18)$ & $\mathrm{C} 7-\mathrm{O} 7-\mathrm{C} 8-\mathrm{O} 6$ & $6.6(2)$ \\
\hline $\mathrm{C} 5-\mathrm{O} 1-\mathrm{C} 1-\mathrm{C} 2$ & $9.9(2)$ & $\mathrm{C} 7-\mathrm{O} 7-\mathrm{C} 8-\mathrm{C} 9$ & $-111.7(2)$ \\
\hline $\mathrm{O} 2-\mathrm{C} 1-\mathrm{C} 2-\mathrm{O} 3$ & $-71.31(18)$ & $\mathrm{C} 7-\mathrm{O} 7-\mathrm{C} 8-\mathrm{C} 13$ & $125.54(17)$ \\
\hline $\mathrm{O} 1-\mathrm{C} 1-\mathrm{C} 2-\mathrm{O} 3$ & $166.90(15)$ & $\mathrm{C} 6-\mathrm{O} 6-\mathrm{C} 8-\mathrm{O} 7$ & $17.8(2)$ \\
\hline $\mathrm{O} 2-\mathrm{C} 1-\mathrm{C} 2-\mathrm{C} 3$ & $167.35(14)$ & $\mathrm{C} 6-\mathrm{O} 6-\mathrm{C} 8-\mathrm{C} 9$ & $137.22(19)$ \\
\hline $\mathrm{O} 1-\mathrm{C} 1-\mathrm{C} 2-\mathrm{C} 3$ & $45.6(2)$ & $\mathrm{C} 6-\mathrm{O} 6-\mathrm{C} 8-\mathrm{C} 13$ & $-99.31(18)$ \\
\hline $\mathrm{C} 14-\mathrm{O} 4-\mathrm{C} 3-\mathrm{C} 2$ & $-147.13(15)$ & $\mathrm{O} 7-\mathrm{C} 8-\mathrm{C} 9-\mathrm{C} 10$ & $-66.1(3)$ \\
\hline $\mathrm{C} 14-\mathrm{O} 4-\mathrm{C} 3-\mathrm{C} 4$ & $-27.62(17)$ & $\mathrm{O} 6-\mathrm{C} 8-\mathrm{C} 9-\mathrm{C} 10$ & $177.7(2)$ \\
\hline $\mathrm{O} 3-\mathrm{C} 2-\mathrm{C} 3-\mathrm{O} 4$ & $-58.95(19)$ & $\mathrm{C} 13-\mathrm{C} 8-\mathrm{C} 9-\mathrm{C} 10$ & $54.6(3)$ \\
\hline $\mathrm{C} 1-\mathrm{C} 2-\mathrm{C} 3-\mathrm{O} 4$ & $62.34(19)$ & $\mathrm{C} 8-\mathrm{C} 9-\mathrm{C} 10-\mathrm{C} 11$ & $-55.9(3)$ \\
\hline $\mathrm{O} 3-\mathrm{C} 2-\mathrm{C} 3-\mathrm{C} 4$ & $-173.70(14)$ & $\mathrm{C} 9-\mathrm{C} 10-\mathrm{C} 11-\mathrm{C} 12$ & $55.7(3)$ \\
\hline $\mathrm{C} 1-\mathrm{C} 2-\mathrm{C} 3-\mathrm{C} 4$ & $-52.4(2)$ & $\mathrm{C} 10-\mathrm{C} 11-\mathrm{C} 12-\mathrm{C} 13$ & $-54.5(3)$ \\
\hline $\mathrm{C} 14-\mathrm{O} 5-\mathrm{C} 4-\mathrm{C} 5$ & $135.78(16)$ & $\mathrm{O} 7-\mathrm{C} 8-\mathrm{C} 13-\mathrm{C} 12$ & $68.4(2)$ \\
\hline $\mathrm{C} 14-\mathrm{O} 5-\mathrm{C} 4-\mathrm{C} 3$ & $15.54(19)$ & $\mathrm{O} 6-\mathrm{C} 8-\mathrm{C} 13-\mathrm{C} 12$ & $-175.94(19)$ \\
\hline $\mathrm{O} 4-\mathrm{C} 3-\mathrm{C} 4-\mathrm{O} 5$ & $7.32(18)$ & $\mathrm{C} 9-\mathrm{C} 8-\mathrm{C} 13-\mathrm{C} 12$ & $-53.9(3)$ \\
\hline $\mathrm{C} 2-\mathrm{C} 3-\mathrm{C} 4-\mathrm{O} 5$ & $125.79(16)$ & $\mathrm{C} 11-\mathrm{C} 12-\mathrm{C} 13-\mathrm{C} 8$ & $53.9(3)$ \\
\hline $\mathrm{O} 4-\mathrm{C} 3-\mathrm{C} 4-\mathrm{C} 5$ & $-111.78(16)$ & $\mathrm{C} 3-\mathrm{O} 4-\mathrm{C} 14-\mathrm{O} 5$ & $37.86(18)$ \\
\hline $\mathrm{C} 2-\mathrm{C} 3-\mathrm{C} 4-\mathrm{C} 5$ & $6.7(2)$ & $\mathrm{C} 3-\mathrm{O} 4-\mathrm{C} 14-\mathrm{C} 15$ & $155.06(16)$ \\
\hline $\mathrm{C} 1-\mathrm{O} 1-\mathrm{C} 5-\mathrm{C} 6$ & $-179.18(15)$ & $\mathrm{C} 3-\mathrm{O} 4-\mathrm{C} 14-\mathrm{C} 19$ & $-81.37(18)$ \\
\hline $\mathrm{C} 1-\mathrm{O} 1-\mathrm{C} 5-\mathrm{C} 4$ & $-56.9(2)$ & $\mathrm{C} 4-\mathrm{O} 5-\mathrm{C} 14-\mathrm{O} 4$ & $-32.95(19)$ \\
\hline
\end{tabular}




$\begin{array}{llll}\mathrm{O} 5-\mathrm{C} 4-\mathrm{C} 5-\mathrm{O} 1 & -69.48(18) & \mathrm{C} 4-\mathrm{O} 5-\mathrm{C} 14-\mathrm{C} 15 & -149.19(17) \\ \mathrm{C} 3-\mathrm{C} 4-\mathrm{C} 5-\mathrm{O} 1 & 46.22(19) & \mathrm{C} 4-\mathrm{O} 5-\mathrm{C} 14-\mathrm{C} 19 & 86.43(18) \\ \mathrm{O} 5-\mathrm{C} 4-\mathrm{C} 5-\mathrm{C} 6 & 49.67(19) & \mathrm{O} 4-\mathrm{C} 14-\mathrm{C} 15-\mathrm{C} 16 & 69.4(2) \\ \mathrm{C} 3-\mathrm{C} 4-\mathrm{C} 5-\mathrm{C} 6 & 165.37(15) & \mathrm{O} 5-\mathrm{C} 14-\mathrm{C} 15-\mathrm{C} 16 & -177.24(18) \\ \mathrm{C} 8-\mathrm{O} 6-\mathrm{C} 6-\mathrm{C} 7 & -33.24(18) & \mathrm{C} 19-\mathrm{C} 14-\mathrm{C} 15-\mathrm{C} 16 & -53.6(2) \\ \mathrm{C} 8-\mathrm{O} 6-\mathrm{C} 6-\mathrm{C} 5 & -156.06(16) & \mathrm{C} 14-\mathrm{C} 15-\mathrm{C} 16-\mathrm{C} 17 & 54.8(3) \\ \mathrm{O} 1-\mathrm{C} 5-\mathrm{C} 6-\mathrm{O} 6 & -71.94(18) & \mathrm{C} 15-\mathrm{C} 16-\mathrm{C} 17-\mathrm{C} 18 & -56.1(3) \\ \mathrm{C} 4-\mathrm{C} 5-\mathrm{C} 6-\mathrm{O} 6 & 166.11(14) & \mathrm{C} 16-\mathrm{C} 17-\mathrm{C} 18-\mathrm{C} 19 & 56.3(3) \\ \mathrm{O} 1-\mathrm{C} 5-\mathrm{C} 6-\mathrm{C} 7 & 173.96(15) & \mathrm{C} 17-\mathrm{C} 18-\mathrm{C} 19-\mathrm{C} 14 & -55.2(3) \\ \mathrm{C} 4-\mathrm{C} 5-\mathrm{C} 6-\mathrm{C} 7 & 52.0(2) & \mathrm{O} 4-\mathrm{C} 14-\mathrm{C} 19-\mathrm{C} 18 & -67.5(2) \\ \mathrm{C} 8-\mathrm{O} 7-\mathrm{C} 7-\mathrm{C} 6 & -26.9(2) & \mathrm{O} 5-\mathrm{C} 14-\mathrm{C} 19-\mathrm{C} 18 & 177.44(17) \\ \mathrm{O} 6-\mathrm{C} 6-\mathrm{C} 7-\mathrm{O} 7 & 36.38(19) & \mathrm{C} 15-\mathrm{C} 14-\mathrm{C} 19-\mathrm{C} 18 & 54.2(2) \\ \mathrm{C} 5-\mathrm{C} 6-\mathrm{C} 7-\mathrm{O} 7 & 155.87(16) & & \end{array}$

Hydrogen-bond geometry $\left(A,{ }^{\circ}\right)$

\begin{tabular}{lllll}
\hline$D-\mathrm{H}^{\cdots} A$ & $D-\mathrm{H}$ & $\mathrm{H} \cdots A$ & $D \cdots A$ & $D-\mathrm{H} \cdots A$ \\
\hline $\mathrm{O} 2-\mathrm{H} 21 \cdots \mathrm{O} 8^{\mathrm{i}}$ & 0.82 & 1.98 & $2.653(3)$ & 139 \\
$\mathrm{O} 3-\mathrm{H} 22 \cdots 6^{\mathrm{ii}}$ & 0.82 & 2.02 & $2.829(2)$ & 171 \\
$\mathrm{O} 8-\mathrm{H} 23 \cdots 3^{\mathrm{i}}$ & 0.82 & 1.92 & $2.727(3)$ & 169 \\
\hline
\end{tabular}

Symmetry codes: (i) $x-1 / 2,-y+3 / 2,-z+1$; (ii) $x+1 / 2,-y+3 / 2,-z+1$.

(Comp_XV) (2R,3R,4R,5S)-5-Allyl-2-[(S)-2,3-dihydroxypropyl]-4-[(phenylsulfonyl)methyl]tetrahydrofuran-3-ol

Crystal data

$\mathrm{C}_{17} \mathrm{H}_{24} \mathrm{O}_{6} \mathrm{~S}$

$M_{r}=356.43$

Orthorhombic, $P 22_{1} 22_{1}$

$a=7.593(6) \AA$

$b=8.542(7) \AA$

$c=26.70(2) \AA$

$V=1732(2) \AA^{3}$

$Z=4$

$F(000)=760.00$

\section{Data collection}

Rigaku XtaLAB mini diffractometer

Detector resolution: 13.653 pixels $\mathrm{mm}^{-1}$ $\omega$ scans

Absorption correction: numerical (NUMABS; Rigaku, 1999)

$T_{\min }=0.887, T_{\max }=0.958$

14279 measured reflections

\section{Refinement}

Refinement on $F^{2}$

$R\left[F^{2}>2 \sigma\left(F^{2}\right)\right]=0.033$

$w R\left(F^{2}\right)=0.082$

$S=1.05$

3942 reflections

220 parameters
$D_{\mathrm{x}}=1.367 \mathrm{Mg} \mathrm{m}^{-3}$

Mo $K \alpha$ radiation, $\lambda=0.71075 \AA$

Cell parameters from 4380 reflections

$\theta=3.1-27.5^{\circ}$

$\mu=0.22 \mathrm{~mm}^{-1}$

$T=200 \mathrm{~K}$

Prism, colorless

$0.40 \times 0.32 \times 0.20 \mathrm{~mm}$

3942 independent reflections

3733 reflections with $F^{2}>2.0 \sigma\left(F^{2}\right)$

$R_{\text {int }}=0.034$

$\theta_{\max }=27.5^{\circ}, \theta_{\min }=3.1^{\circ}$

$h=-9 \rightarrow 9$

$k=-11 \rightarrow 11$

$l=-34 \rightarrow 34$

0 restraints

Primary atom site location: structure-invariant direct methods

Secondary atom site location: difference Fourier map 
Hydrogen site location: inferred from

neighbouring sites

$\mathrm{H}$-atom parameters constrained

$w=1 /\left[\sigma^{2}\left(F_{\mathrm{o}}^{2}\right)+(0.0405 P)^{2}+0.1659 P\right]$

where $P=\left(F_{\mathrm{o}}{ }^{2}+2 F_{\mathrm{c}}{ }^{2}\right) / 3$

$(\Delta / \sigma)_{\max }=0.002$
$\Delta \rho_{\max }=0.23$ e $\AA^{-3}$

$\Delta \rho_{\min }=-0.24$ e $\AA^{-3}$

Absolute structure: Flack $x$ determined using

1454 quotients [(I+)-(I-)]/[(I+)+(I-)] (Parsons et al., 2013)

Absolute structure parameter: 0.00 (3)

Special details

Geometry. All esds (except the esd in the dihedral angle between two 1.s. planes) are estimated using the full covariance matrix. The cell esds are taken into account individually in the estimation of esds in distances, angles and torsion angles; correlations between esds in cell parameters are only used when they are defined by crystal symmetry. An approximate (isotropic) treatment of cell esds is used for estimating esds involving l.s. planes.

Refinement. Refinement was performed using all reflections. The weighted R-factor (wR) and goodness of fit (S) are based on $\mathrm{F}^{2}$. R-factor (gt) are based on $\mathrm{F}$. The threshold expression of $\mathrm{F}^{2}>2.0 \operatorname{sigma}\left(\mathrm{F}^{2}\right)$ is used only for calculating Rfactor (gt).

Neutral-atom scattering factors were taken from international tables for crystallography, Vol. C, Table 6.1.1.4. Anomalous dispersion effects were included in Fcalc (Ibers \& Hamilton, 1964); the values for ?f' and ?f" were extracted from international tables of crystallography (Creagh \& McAuley, 1992). The values for the mass attenuation coefficients are those of Creagh and Hubbell.

Creagh, D. C. \& Hubbell, J.H..; "International Tables for Crystallography", Vol C, (A.J.C. Wilson, ed.), Kluwer Academic Publishers, Boston, Table 4.2.4.3, pages 200-206 (1992).

Creagh, D. C. \& McAuley, W. J. (1992). International Tables for Crystallography, (A. J. C. Wilson, ed.), Kluwer Academic Publishers, Boston, Vol C, Table 4.2.6.8, 219-222.

Ibers, J. A. \& Hamilton, W. C. (1964). Acta Cryst. 17, 781-782.

Fractional atomic coordinates and isotropic or equivalent isotropic displacement parameters $\left(\AA^{2}\right)$

\begin{tabular}{|c|c|c|c|c|}
\hline & $x$ & $y$ & $z$ & $U_{\text {iso }} * / U_{\text {eq }}$ \\
\hline S1 & $0.75191(7)$ & $0.69616(6)$ & $0.55350(2)$ & $0.03182(14)$ \\
\hline $\mathrm{O} 1$ & $0.26736(18)$ & $0.69593(16)$ & $0.68646(5)$ & $0.0270(3)$ \\
\hline $\mathrm{O} 2$ & -0.16817 (19) & $0.34917(19)$ & $0.72260(6)$ & 0.0327 (4) \\
\hline H18 & -0.1726 & 0.3074 & 0.7511 & $0.039 *$ \\
\hline $\mathrm{O} 3$ & $0.1105(2)$ & $0.3635(2)$ & $0.79208(5)$ & $0.0328(4)$ \\
\hline H19 & 0.1752 & 0.2837 & 0.7923 & $0.039^{*}$ \\
\hline $\mathrm{O} 4$ & $0.64460(18)$ & $0.61630(18)$ & $0.70728(5)$ & $0.0284(3)$ \\
\hline $\mathrm{H} 20$ & 0.7053 & 0.5376 & 0.7149 & $0.034 *$ \\
\hline O5 & $0.8699(2)$ & $0.6311(2)$ & $0.58990(7)$ & $0.0467(5)$ \\
\hline O6 & $0.7510(3)$ & $0.6297(2)$ & $0.50392(6)$ & $0.0502(5)$ \\
\hline $\mathrm{C} 1$ & $0.3456(3)$ & $0.5447(2)$ & $0.68089(7)$ & $0.0241(4)$ \\
\hline H1 & 0.2854 & 0.4884 & 0.6528 & $0.029 *$ \\
\hline $\mathrm{C} 2$ & $0.5358(2)$ & $0.5797(2)$ & $0.66544(7)$ & $0.0221(4)$ \\
\hline $\mathrm{H} 2$ & 0.5864 & 0.4906 & 0.6458 & $0.027 *$ \\
\hline $\mathrm{C} 3$ & $0.5122(2)$ & $0.7255(2)$ & $0.63198(7)$ & $0.0228(4)$ \\
\hline H3 & 0.5996 & 0.8075 & 0.6418 & $0.027 *$ \\
\hline $\mathrm{C} 4$ & $0.3228(3)$ & $0.7839(2)$ & $0.64351(7)$ & $0.0251(4)$ \\
\hline $\mathrm{H} 4$ & 0.2441 & 0.7590 & 0.6145 & $0.030^{*}$ \\
\hline $\mathrm{C} 5$ & $0.3185(3)$ & $0.4530(3)$ & $0.72883(8)$ & $0.0277(4)$ \\
\hline $\mathrm{H} 5 \mathrm{~A}$ & 0.3862 & 0.5039 & 0.7560 & $0.033^{*}$ \\
\hline $\mathrm{H} 5 \mathrm{~B}$ & 0.3664 & 0.3462 & 0.7243 & $0.033^{*}$ \\
\hline C6 & $0.1256(3)$ & $0.4405(2)$ & $0.74488(7)$ & $0.0247(4)$ \\
\hline H6 & 0.0794 & 0.5494 & 0.7491 & $0.030^{*}$ \\
\hline
\end{tabular}




$\begin{array}{lllll}\text { C7 } & 0.0107(3) & 0.3587(3) & 0.70659(8) & 0.0299(4) \\ \text { H7A } & 0.0164 & 0.4163 & 0.6745 & 0.036^{*} \\ \text { H7B } & 0.0565 & 0.2517 & 0.7008 & 0.036^{*} \\ \text { C8 } & 0.5323(3) & 0.6877(3) & 0.57634(7) & 0.0280(4) \\ \text { H8A } & 0.4594 & 0.7621 & 0.5569 & 0.034^{*} \\ \text { H8B } & 0.4854 & 0.5813 & 0.5702 & 0.034^{*} \\ \text { C9 } & 0.3069(3) & 0.9562(2) & 0.65609(8) & 0.0292(4) \\ \text { H9A } & 0.1841 & 0.9789 & 0.6662 & 0.035^{*} \\ \text { H9B } & 0.3842 & 0.9801 & 0.6850 & 0.035^{*} \\ \text { C10 } & 0.3560(3) & 1.0602(3) & 0.61316(9) & 0.0350(5) \\ \text { H10 } & 0.2976 & 1.0449 & 0.5821 & 0.042^{*} \\ \text { C11 } & 0.4748(4) & 1.1710(3) & 0.61602(10) & 0.0475(6) \\ \text { H11A } & 0.5353 & 1.1889 & 0.6466 & 0.057^{*} \\ \text { H11B } & 0.5004 & 1.2334 & 0.5875 & 0.057^{*} \\ \text { C12 } & 0.7918(3) & 0.8995(3) & 0.54793(8) & 0.0309(5) \\ \text { C13 } & 0.8810(3) & 0.9767(3) & 0.58547(10) & 0.0416(6) \\ \text { H13 } & 0.9228 & 0.9217 & 0.6140 & 0.050^{*} \\ \text { C14 } & 0.9085(4) & 1.1358(4) & 0.58069(13) & 0.0564(7) \\ \text { H14 } & 0.9690 & 1.1911 & 0.6063 & 0.068^{*} \\ \text { C15 } & 0.8489(4) & 1.2146(4) & 0.53927(14) & 0.0605(9) \\ \text { H15 } & 0.8698 & 1.3238 & 0.5362 & 0.073^{*} \\ \text { C16 } & 0.7584(4) & 1.1360(3) & 0.50181(12) & 0.0529(7) \\ \text { H16 } & 0.7167 & 1.1915 & 0.4733 & 0.064^{*} \\ \text { C17 } & 0.7289(3) & 0.9771(3) & 0.50593(9) & 0.0386(5) \\ \text { H17 } & 0.6669 & 0.9220 & 0.4805 & 0.046^{*}\end{array}$

Atomic displacement parameters $\left(\AA^{2}\right)$

\begin{tabular}{lllllll}
\hline & $U^{11}$ & $U^{22}$ & $U^{33}$ & $U^{12}$ & $U^{13}$ & $U^{23}$ \\
\hline S1 & $0.0310(3)$ & $0.0329(3)$ & $0.0315(3)$ & $0.0026(2)$ & $0.0104(2)$ & $0.0010(2)$ \\
O1 & $0.0278(7)$ & $0.0240(7)$ & $0.0293(6)$ & $0.0051(7)$ & $0.0081(6)$ & $0.0045(5)$ \\
O2 & $0.0242(7)$ & $0.0388(9)$ & $0.0351(8)$ & $-0.0017(6)$ & $0.0005(6)$ & $0.0113(6)$ \\
O3 & $0.0306(8)$ & $0.0414(9)$ & $0.0263(7)$ & $0.0036(7)$ & $0.0059(6)$ & $0.0081(6)$ \\
O4 & $0.0253(7)$ & $0.0307(8)$ & $0.0292(7)$ & $0.0008(6)$ & $-0.0051(6)$ & $0.0030(6)$ \\
O5 & $0.0337(9)$ & $0.0484(10)$ & $0.0582(11)$ & $0.0123(8)$ & $0.0058(8)$ & $0.0165(9)$ \\
O6 & $0.0644(11)$ & $0.0472(10)$ & $0.0389(9)$ & $-0.0066(10)$ & $0.0241(10)$ & $-0.0119(7)$ \\
C1 & $0.0240(9)$ & $0.0223(10)$ & $0.0259(9)$ & $0.0003(8)$ & $0.0020(7)$ & $0.0009(7)$ \\
C2 & $0.0217(9)$ & $0.0218(10)$ & $0.0228(9)$ & $0.0013(7)$ & $0.0018(7)$ & $-0.0001(7)$ \\
C3 & $0.0211(8)$ & $0.0236(10)$ & $0.0238(9)$ & $-0.0001(8)$ & $0.0012(7)$ & $0.0011(7)$ \\
C4 & $0.0225(9)$ & $0.0284(11)$ & $0.0244(9)$ & $0.0016(8)$ & $0.0015(7)$ & $0.0031(8)$ \\
C5 & $0.0228(9)$ & $0.0301(11)$ & $0.0301(10)$ & $0.0014(8)$ & $0.0027(8)$ & $0.0074(8)$ \\
C6 & $0.0255(9)$ & $0.0225(10)$ & $0.0261(9)$ & $0.0010(8)$ & $0.0037(8)$ & $0.0046(8)$ \\
C7 & $0.0261(9)$ & $0.0348(12)$ & $0.0289(10)$ & $-0.0030(9)$ & $0.0041(8)$ & $0.0015(8)$ \\
C8 & $0.0250(9)$ & $0.0356(11)$ & $0.0233(9)$ & $-0.0028(9)$ & $0.0017(7)$ & $0.0019(9)$ \\
C9 & $0.0298(10)$ & $0.0264(11)$ & $0.0315(10)$ & $0.0042(8)$ & $0.0017(8)$ & $0.0019(8)$ \\
C10 & $0.0398(12)$ & $0.0289(12)$ & $0.0364(11)$ & $0.0082(10)$ & $0.0049(10)$ & $0.0042(9)$ \\
C11 & $0.0582(16)$ & $0.0312(13)$ & $0.0531(15)$ & $-0.0015(12)$ & $0.0139(13)$ & $0.0030(11)$ \\
C12 & $0.0246(9)$ & $0.0372(12)$ & $0.0311(10)$ & $0.0003(9)$ & $0.0066(8)$ & $0.0015(9)$
\end{tabular}




$\begin{array}{lllllll}\mathrm{C} 13 & 0.0338(12) & 0.0479(15) & 0.0432(13) & -0.0022(11) & -0.0006(10) & -0.0030(11) \\ \mathrm{C} 14 & 0.0419(14) & 0.0501(17) & 0.077(2) & -0.0097(14) & 0.0021(14) & -0.0164(15) \\ \text { C15 } & 0.0414(14) & 0.0361(15) & 0.104(3) & -0.0017(13) & 0.0187(16) & 0.0052(16) \\ \text { C16 } & 0.0389(13) & 0.0508(16) & 0.0691(17) & 0.0089(13) & 0.0140(14) & 0.0251(14) \\ \text { C17 } & 0.0317(12) & 0.0471(14) & 0.0370(11) & 0.0027(11) & 0.0055(10) & 0.0073(10)\end{array}$

Geometric parameters $\left(\AA,{ }^{\circ}\right)$

\begin{tabular}{|c|c|c|c|}
\hline $\mathrm{S} 1-\mathrm{O} 5$ & 1.4339 (19) & $\mathrm{C} 6-\mathrm{C} 7$ & $1.515(3)$ \\
\hline $\mathrm{S} 1-\mathrm{O} 6$ & $1.4403(19)$ & $\mathrm{C} 6-\mathrm{H} 6$ & 1.0000 \\
\hline $\mathrm{S} 1-\mathrm{C} 12$ & $1.769(3)$ & $\mathrm{C} 7-\mathrm{H} 7 \mathrm{~A}$ & 0.9900 \\
\hline $\mathrm{S} 1-\mathrm{C} 8$ & $1.777(2)$ & $\mathrm{C} 7-\mathrm{H} 7 \mathrm{~B}$ & 0.9900 \\
\hline $\mathrm{O} 1-\mathrm{C} 1$ & $1.430(3)$ & $\mathrm{C} 8-\mathrm{H} 8 \mathrm{~A}$ & 0.9900 \\
\hline $\mathrm{O} 1-\mathrm{C} 4$ & $1.434(2)$ & $\mathrm{C} 8-\mathrm{H} 8 \mathrm{~B}$ & 0.9900 \\
\hline $\mathrm{O} 2-\mathrm{C} 7$ & $1.426(3)$ & $\mathrm{C} 9-\mathrm{C} 10$ & $1.497(3)$ \\
\hline $\mathrm{O} 2-\mathrm{H} 18$ & 0.8400 & C9-H9A & 0.9900 \\
\hline $\mathrm{O} 3-\mathrm{C} 6$ & $1.426(2)$ & C9-H9B & 0.9900 \\
\hline $\mathrm{O} 3-\mathrm{H} 19$ & 0.8400 & $\mathrm{C} 10-\mathrm{C} 11$ & $1.310(4)$ \\
\hline $\mathrm{O} 4-\mathrm{C} 2$ & $1.424(2)$ & $\mathrm{C} 10-\mathrm{H} 10$ & 0.9500 \\
\hline $\mathrm{O} 4-\mathrm{H} 20$ & 0.8400 & C11-H11A & 0.9500 \\
\hline $\mathrm{C} 1-\mathrm{C} 5$ & $1.514(3)$ & C11-H11B & 0.9500 \\
\hline $\mathrm{C} 1-\mathrm{C} 2$ & $1.531(3)$ & $\mathrm{C} 12-\mathrm{C} 13$ & $1.378(3)$ \\
\hline $\mathrm{C} 1-\mathrm{H} 1$ & 1.0000 & $\mathrm{C} 12-\mathrm{C} 17$ & $1.388(3)$ \\
\hline $\mathrm{C} 2-\mathrm{C} 3$ & $1.543(3)$ & $\mathrm{C} 13-\mathrm{C} 14$ & $1.381(4)$ \\
\hline $\mathrm{C} 2-\mathrm{H} 2$ & 1.0000 & $\mathrm{C} 13-\mathrm{H} 13$ & 0.9500 \\
\hline $\mathrm{C} 3-\mathrm{C} 8$ & $1.528(3)$ & $\mathrm{C} 14-\mathrm{C} 15$ & $1.371(5)$ \\
\hline $\mathrm{C} 3-\mathrm{C} 4$ & $1.554(3)$ & C14-H14 & 0.9500 \\
\hline $\mathrm{C} 3-\mathrm{H} 3$ & 1.0000 & $\mathrm{C} 15-\mathrm{C} 16$ & $1.387(5)$ \\
\hline $\mathrm{C} 4-\mathrm{C} 9$ & $1.514(3)$ & C15-H15 & 0.9500 \\
\hline $\mathrm{C} 4-\mathrm{H} 4$ & 1.0000 & $\mathrm{C} 16-\mathrm{C} 17$ & $1.380(4)$ \\
\hline $\mathrm{C} 5-\mathrm{C} 6$ & $1.530(3)$ & $\mathrm{C} 16-\mathrm{H} 16$ & 0.9500 \\
\hline $\mathrm{C} 5-\mathrm{H} 5 \mathrm{~A}$ & 0.9900 & C17-H17 & 0.9500 \\
\hline C5-H5B & 0.9900 & & \\
\hline $\mathrm{O} 5-\mathrm{S} 1-\mathrm{O} 6$ & $118.24(13)$ & $\mathrm{C} 7-\mathrm{C} 6-\mathrm{H} 6$ & 107.6 \\
\hline $\mathrm{O} 5-\mathrm{S} 1-\mathrm{C} 12$ & $109.31(11)$ & $\mathrm{C} 5-\mathrm{C} 6-\mathrm{H} 6$ & 107.6 \\
\hline $\mathrm{O} 6-\mathrm{S} 1-\mathrm{C} 12$ & $108.07(11)$ & $\mathrm{O} 2-\mathrm{C} 7-\mathrm{C} 6$ & $111.86(17)$ \\
\hline $\mathrm{O} 5-\mathrm{S} 1-\mathrm{C} 8$ & $109.73(11)$ & $\mathrm{O} 2-\mathrm{C} 7-\mathrm{H} 7 \mathrm{~A}$ & 109.2 \\
\hline $\mathrm{O} 6-\mathrm{S} 1-\mathrm{C} 8$ & $107.17(12)$ & $\mathrm{C} 6-\mathrm{C} 7-\mathrm{H} 7 \mathrm{~A}$ & 109.2 \\
\hline $\mathrm{C} 12-\mathrm{S} 1-\mathrm{C} 8$ & $103.27(10)$ & $\mathrm{O} 2-\mathrm{C} 7-\mathrm{H} 7 \mathrm{~B}$ & 109.2 \\
\hline $\mathrm{C} 1-\mathrm{O} 1-\mathrm{C} 4$ & $105.59(14)$ & $\mathrm{C} 6-\mathrm{C} 7-\mathrm{H} 7 \mathrm{~B}$ & 109.2 \\
\hline $\mathrm{C} 7-\mathrm{O} 2-\mathrm{H} 18$ & 109.5 & $\mathrm{H} 7 \mathrm{~A}-\mathrm{C} 7-\mathrm{H} 7 \mathrm{~B}$ & 107.9 \\
\hline $\mathrm{C} 6-\mathrm{O} 3-\mathrm{H} 19$ & 109.5 & $\mathrm{C} 3-\mathrm{C} 8-\mathrm{S} 1$ & $114.77(14)$ \\
\hline $\mathrm{C} 2-\mathrm{O} 4-\mathrm{H} 20$ & 109.5 & $\mathrm{C} 3-\mathrm{C} 8-\mathrm{H} 8 \mathrm{~A}$ & 108.6 \\
\hline $\mathrm{O} 1-\mathrm{C} 1-\mathrm{C} 5$ & $108.84(16)$ & $\mathrm{S} 1-\mathrm{C} 8-\mathrm{H} 8 \mathrm{~A}$ & 108.6 \\
\hline $\mathrm{O} 1-\mathrm{C} 1-\mathrm{C} 2$ & $104.07(16)$ & $\mathrm{C} 3-\mathrm{C} 8-\mathrm{H} 8 \mathrm{~B}$ & 108.6 \\
\hline $\mathrm{C} 5-\mathrm{C} 1-\mathrm{C} 2$ & $117.17(16)$ & $\mathrm{S} 1-\mathrm{C} 8-\mathrm{H} 8 \mathrm{~B}$ & 108.6 \\
\hline $\mathrm{O} 1-\mathrm{C} 1-\mathrm{H} 1$ & 108.8 & $\mathrm{H} 8 \mathrm{~A}-\mathrm{C} 8-\mathrm{H} 8 \mathrm{~B}$ & 107.5 \\
\hline
\end{tabular}




\begin{tabular}{|c|c|c|c|}
\hline $\mathrm{C} 5-\mathrm{C} 1-\mathrm{H} 1$ & 108.8 & $\mathrm{C} 10-\mathrm{C} 9-\mathrm{C} 4$ & $112.76(18)$ \\
\hline $\mathrm{C} 2-\mathrm{C} 1-\mathrm{H} 1$ & 108.8 & $\mathrm{C} 10-\mathrm{C} 9-\mathrm{H} 9 \mathrm{~A}$ & 109.0 \\
\hline $\mathrm{O} 4-\mathrm{C} 2-\mathrm{C} 1$ & $112.26(16)$ & $\mathrm{C} 4-\mathrm{C} 9-\mathrm{H} 9 \mathrm{~A}$ & 109.0 \\
\hline $\mathrm{O} 4-\mathrm{C} 2-\mathrm{C} 3$ & $110.11(16)$ & $\mathrm{C} 10-\mathrm{C} 9-\mathrm{H} 9 \mathrm{~B}$ & 109.0 \\
\hline $\mathrm{C} 1-\mathrm{C} 2-\mathrm{C} 3$ & $101.79(15)$ & $\mathrm{C} 4-\mathrm{C} 9-\mathrm{H} 9 \mathrm{~B}$ & 109.0 \\
\hline $\mathrm{O} 4-\mathrm{C} 2-\mathrm{H} 2$ & 110.8 & $\mathrm{H} 9 \mathrm{~A}-\mathrm{C} 9-\mathrm{H} 9 \mathrm{~B}$ & 107.8 \\
\hline $\mathrm{C} 1-\mathrm{C} 2-\mathrm{H} 2$ & 110.8 & $\mathrm{C} 11-\mathrm{C} 10-\mathrm{C} 9$ & $123.7(2)$ \\
\hline $\mathrm{C} 3-\mathrm{C} 2-\mathrm{H} 2$ & 110.8 & $\mathrm{C} 11-\mathrm{C} 10-\mathrm{H} 10$ & 118.1 \\
\hline $\mathrm{C} 8-\mathrm{C} 3-\mathrm{C} 2$ & $112.39(17)$ & $\mathrm{C} 9-\mathrm{C} 10-\mathrm{H} 10$ & 118.1 \\
\hline $\mathrm{C} 8-\mathrm{C} 3-\mathrm{C} 4$ & $110.67(16)$ & $\mathrm{C} 10-\mathrm{C} 11-\mathrm{H} 11 \mathrm{~A}$ & 120.0 \\
\hline $\mathrm{C} 2-\mathrm{C} 3-\mathrm{C} 4$ & $104.60(15)$ & $\mathrm{C} 10-\mathrm{C} 11-\mathrm{H} 11 \mathrm{~B}$ & 120.0 \\
\hline $\mathrm{C} 8-\mathrm{C} 3-\mathrm{H} 3$ & 109.7 & $\mathrm{H} 11 \mathrm{~A}-\mathrm{C} 11-\mathrm{H} 11 \mathrm{~B}$ & 120.0 \\
\hline $\mathrm{C} 2-\mathrm{C} 3-\mathrm{H} 3$ & 109.7 & $\mathrm{C} 13-\mathrm{C} 12-\mathrm{C} 17$ & $121.9(2)$ \\
\hline $\mathrm{C} 4-\mathrm{C} 3-\mathrm{H} 3$ & 109.7 & $\mathrm{C} 13-\mathrm{C} 12-\mathrm{S} 1$ & $119.54(19)$ \\
\hline $\mathrm{O} 1-\mathrm{C} 4-\mathrm{C} 9$ & $107.97(16)$ & $\mathrm{C} 17-\mathrm{C} 12-\mathrm{S} 1$ & $118.57(18)$ \\
\hline $\mathrm{O} 1-\mathrm{C} 4-\mathrm{C} 3$ & $105.16(15)$ & $\mathrm{C} 12-\mathrm{C} 13-\mathrm{C} 14$ & $118.6(3)$ \\
\hline $\mathrm{C} 9-\mathrm{C} 4-\mathrm{C} 3$ & $115.47(17)$ & $\mathrm{C} 12-\mathrm{C} 13-\mathrm{H} 13$ & 120.7 \\
\hline $\mathrm{O} 1-\mathrm{C} 4-\mathrm{H} 4$ & 109.3 & $\mathrm{C} 14-\mathrm{C} 13-\mathrm{H} 13$ & 120.7 \\
\hline $\mathrm{C} 9-\mathrm{C} 4-\mathrm{H} 4$ & 109.3 & $\mathrm{C} 15-\mathrm{C} 14-\mathrm{C} 13$ & 120.5 \\
\hline $\mathrm{C} 3-\mathrm{C} 4-\mathrm{H} 4$ & 109.3 & $\mathrm{C} 15-\mathrm{C} 14-\mathrm{H} 14$ & 119.7 \\
\hline $\mathrm{C} 1-\mathrm{C} 5-\mathrm{C} 6$ & $113.76(16)$ & $\mathrm{C} 13-\mathrm{C} 14-\mathrm{H} 14$ & 119.7 \\
\hline $\mathrm{C} 1-\mathrm{C} 5-\mathrm{H} 5 \mathrm{~A}$ & 108.8 & $\mathrm{C} 14-\mathrm{C} 15-\mathrm{C} 16$ & $120.5(3)$ \\
\hline $\mathrm{C} 6-\mathrm{C} 5-\mathrm{H} 5 \mathrm{~A}$ & 108.8 & $\mathrm{C} 14-\mathrm{C} 15-\mathrm{H} 15$ & 119.7 \\
\hline $\mathrm{C} 1-\mathrm{C} 5-\mathrm{H} 5 \mathrm{~B}$ & 108.8 & $\mathrm{C} 16-\mathrm{C} 15-\mathrm{H} 15$ & 119.7 \\
\hline $\mathrm{C} 6-\mathrm{C} 5-\mathrm{H} 5 \mathrm{~B}$ & 108.8 & $\mathrm{C} 17-\mathrm{C} 16-\mathrm{C} 15$ & $119.9(3)$ \\
\hline $\mathrm{H} 5 \mathrm{~A}-\mathrm{C} 5-\mathrm{H} 5 \mathrm{~B}$ & 107.7 & $\mathrm{C} 17-\mathrm{C} 16-\mathrm{H} 16$ & 120.0 \\
\hline $\mathrm{O} 3-\mathrm{C} 6-\mathrm{C} 7$ & $109.69(17)$ & $\mathrm{C} 15-\mathrm{C} 16-\mathrm{H} 16$ & 120.0 \\
\hline $\mathrm{O} 3-\mathrm{C} 6-\mathrm{C} 5$ & $110.90(15)$ & $\mathrm{C} 16-\mathrm{C} 17-\mathrm{C} 12$ & $118.6(2)$ \\
\hline $\mathrm{C} 7-\mathrm{C} 6-\mathrm{C} 5$ & $113.23(17)$ & $\mathrm{C} 16-\mathrm{C} 17-\mathrm{H} 17$ & 120.7 \\
\hline $\mathrm{O} 3-\mathrm{C} 6-\mathrm{H} 6$ & 107.6 & $\mathrm{C} 12-\mathrm{C} 17-\mathrm{H} 17$ & 120.7 \\
\hline $\mathrm{C} 4-\mathrm{O} 1-\mathrm{C} 1-\mathrm{C} 5$ & $170.74(15)$ & $\mathrm{C} 2-\mathrm{C} 3-\mathrm{C} 8-\mathrm{S} 1$ & $-87.49(19)$ \\
\hline $\mathrm{C} 4-\mathrm{O} 1-\mathrm{C} 1-\mathrm{C} 2$ & $45.09(18)$ & $\mathrm{C} 4-\mathrm{C} 3-\mathrm{C} 8-\mathrm{S} 1$ & $155.97(15)$ \\
\hline $\mathrm{O} 1-\mathrm{C} 1-\mathrm{C} 2-\mathrm{O} 4$ & $81.59(18)$ & $\mathrm{O} 5-\mathrm{S} 1-\mathrm{C} 8-\mathrm{C} 3$ & $39.8(2)$ \\
\hline $\mathrm{C} 5-\mathrm{C} 1-\mathrm{C} 2-\mathrm{O} 4$ & $-38.6(2)$ & $\mathrm{O} 6-\mathrm{S} 1-\mathrm{C} 8-\mathrm{C} 3$ & $169.40(16)$ \\
\hline $\mathrm{O} 1-\mathrm{C} 1-\mathrm{C} 2-\mathrm{C} 3$ & $-36.12(18)$ & $\mathrm{C} 12-\mathrm{S} 1-\mathrm{C} 8-\mathrm{C} 3$ & $-76.62(18)$ \\
\hline $\mathrm{C} 5-\mathrm{C} 1-\mathrm{C} 2-\mathrm{C} 3$ & $-156.31(17)$ & $\mathrm{O} 1-\mathrm{C} 4-\mathrm{C} 9-\mathrm{C} 10$ & $-178.13(17)$ \\
\hline $\mathrm{O} 4-\mathrm{C} 2-\mathrm{C} 3-\mathrm{C} 8$ & $135.57(17)$ & $\mathrm{C} 3-\mathrm{C} 4-\mathrm{C} 9-\mathrm{C} 10$ & $64.6(2)$ \\
\hline $\mathrm{C} 1-\mathrm{C} 2-\mathrm{C} 3-\mathrm{C} 8$ & $-105.19(17)$ & $\mathrm{C} 4-\mathrm{C} 9-\mathrm{C} 10-\mathrm{C} 11$ & $-125.5(3)$ \\
\hline $\mathrm{O} 4-\mathrm{C} 2-\mathrm{C} 3-\mathrm{C} 4$ & $-104.31(17)$ & $\mathrm{O} 5-\mathrm{S} 1-\mathrm{C} 12-\mathrm{C} 13$ & $-18.8(2)$ \\
\hline $\mathrm{C} 1-\mathrm{C} 2-\mathrm{C} 3-\mathrm{C} 4$ & $14.93(19)$ & $\mathrm{O} 6-\mathrm{S} 1-\mathrm{C} 12-\mathrm{C} 13$ & $-148.67(19)$ \\
\hline $\mathrm{C} 1-\mathrm{O} 1-\mathrm{C} 4-\mathrm{C} 9$ & $-158.33(16)$ & $\mathrm{C} 8-\mathrm{S} 1-\mathrm{C} 12-\mathrm{C} 13$ & $98.00(19)$ \\
\hline $\mathrm{C} 1-\mathrm{O} 1-\mathrm{C} 4-\mathrm{C} 3$ & $-34.53(19)$ & $\mathrm{O} 5-\mathrm{S} 1-\mathrm{C} 12-\mathrm{C} 17$ & $162.38(17)$ \\
\hline $\mathrm{C} 8-\mathrm{C} 3-\mathrm{C} 4-\mathrm{O} 1$ & $131.96(18)$ & $\mathrm{O} 6-\mathrm{S} 1-\mathrm{C} 12-\mathrm{C} 17$ & $32.5(2)$ \\
\hline $\mathrm{C} 2-\mathrm{C} 3-\mathrm{C} 4-\mathrm{O} 1$ & $10.70(19)$ & $\mathrm{C} 8-\mathrm{S} 1-\mathrm{C} 12-\mathrm{C} 17$ & $-80.87(19)$ \\
\hline $\mathrm{C} 8-\mathrm{C} 3-\mathrm{C} 4-\mathrm{C} 9$ & $-109.15(19)$ & $\mathrm{C} 17-\mathrm{C} 12-\mathrm{C} 13-\mathrm{C} 14$ & $-0.2(4)$ \\
\hline $\mathrm{C} 2-\mathrm{C} 3-\mathrm{C} 4-\mathrm{C} 9$ & $129.58(18)$ & $\mathrm{S} 1-\mathrm{C} 12-\mathrm{C} 13-\mathrm{C} 14$ & $-179.1(2)$ \\
\hline $\mathrm{O} 1-\mathrm{C} 1-\mathrm{C} 5-\mathrm{C} 6$ & $55.3(2)$ & $\mathrm{C} 12-\mathrm{C} 13-\mathrm{C} 14-\mathrm{C} 15$ & $-0.4(4)$ \\
\hline
\end{tabular}




$\begin{array}{llll}\mathrm{C} 2-\mathrm{C} 1-\mathrm{C} 5-\mathrm{C} 6 & 172.89(17) & \mathrm{C} 13-\mathrm{C} 14-\mathrm{C} 15-\mathrm{C} 16 & 0.8(4) \\ \mathrm{C} 1-\mathrm{C} 5-\mathrm{C} 6-\mathrm{O} 3 & -175.56(17) & \mathrm{C} 14-\mathrm{C} 15-\mathrm{C} 16-\mathrm{C} 17 & -0.5(4) \\ \mathrm{C} 1-\mathrm{C} 5-\mathrm{C} 6-\mathrm{C} 7 & 60.6(2) & \mathrm{C} 15-\mathrm{C} 16-\mathrm{C} 17-\mathrm{C} 12 & -0.1(4) \\ \mathrm{O} 3-\mathrm{C} 6-\mathrm{C} 7-\mathrm{O} 2 & 55.6(2) & \mathrm{C} 13-\mathrm{C} 12-\mathrm{C} 17-\mathrm{C} 16 & 0.5(3) \\ \mathrm{C} 5-\mathrm{C} 6-\mathrm{C} 7-\mathrm{O} 2 & -179.89(16) & \mathrm{S} 1-\mathrm{C} 12-\mathrm{C} 17-\mathrm{C} 16 & 179.33(18)\end{array}$

Hydrogen-bond geometry $\left(\AA,{ }^{\circ}\right)$

\begin{tabular}{lllll}
\hline$D-\mathrm{H} \cdots A$ & $D-\mathrm{H}$ & $\mathrm{H} \cdots A$ & $D \cdots A$ & $D-\mathrm{H} \cdots A$ \\
\hline $\mathrm{O} 2-\mathrm{H} 18 \cdots \mathrm{O} 1^{\mathrm{i}}$ & 0.84 & 2.05 & $2.859(3)$ & 161 \\
$\mathrm{O} 2-\mathrm{H} 18 \cdots \mathrm{O} 3$ & 0.84 & 2.46 & $2.817(3)$ & 107 \\
$\mathrm{O} 3-\mathrm{H} 19 \cdots \mathrm{O} 4^{\mathrm{ii}}$ & 0.84 & 1.98 & $2.813(3)$ & 172 \\
$\mathrm{O} 4-\mathrm{H} 20 \cdots \mathrm{O} 2^{\mathrm{iii}}$ & 0.84 & 1.89 & $2.719(3)$ & 171 \\
\hline
\end{tabular}

Symmetry codes: (i) $-x, y-1 / 2,-z+3 / 2$; (ii) $-x+1, y-1 / 2,-z+3 / 2$; (iii) $x+1, y, z$. 